Vol. 4, No. 2, Oct 2015, p-ISSN: 2252-5793, hlm. 175-210

\title{
IMPLEMENTASI PENGEMBANGAN KARAKTER KEAGAMAAN DAN Potensi KeCERDASAN ANAK USIa DinI (Studi Kasus di PAUD Ceria dan Tamasha ValaQ PangkalPinang)
}

\author{
Soleha1 $^{1}$ Adian Husaini'a, Endin Mujahidin'2, Didin Saefuddin ${ }^{3}$ \\ ${ }^{1}$ STAIN Syaikh Abdurrahman Siddik Bangka Belitung, Indonesia \\ 2a(Coresponding author) Universitas Ibn Khaldun Bogor, Indonesia \\ ahusaini@uika-bogor.ac.id dan ahusaini @yahoo.com \\ 2 Universitas Ibn Khaldun Bogor \\ 3Universitas Islam Negeri Jakarta
}

\begin{abstract}
The existence of Early Childhood Education (PAUD) is immensely needed in the midst of our society. Still, there are many PAUD wich is not conduct yet their development process as required by mandate. Their existence are rarely concern and prioritize the quality of their institution, but quantity. Consequently, there are many PAUD which still have not conducted their learning process accordance with regulation, that is Permendiknas No. 58 year 2009 on standard of Early Childhood Education (PAUD). This research focused on the problem of implementation of early childhood religious character and its intelligence potentials, especially in PAUD Ceria dan Tamasha Valaq. Through its development the research tried to see the growth of religious and moral values, while the intelleigence was saw through physical, cognitive, language and socioemotional potential.On the other side, the educational process was conducted using learn and play, exemplary, and internalization method apllied to the learners/kids. The research used a descriptive approach that tried to revealed phenomenon holistically and contextually by colleting data. The Early Childhood Education (PAUD) where this reasearh conducted is PAUD Ceria dan Tamasha Valaq in Pangkalpinang. Source of data is derived from Pangkal Pinang national department of education, Kindergarden Teacher Association (IGRA), Association of Indonesian Early Childhood Education (HIMPAUDI) Province Pangkalpinang, PAUD's manager, teachers, representation of learners and their parents. Analyses method used by this research is qualitative method which used to find implementation of religious character intelligence potentials development in both of PAUD. The result showed that the process of learning conducted by both of PAUD already meet the standard of Early Childhood Education. Eventhough, each of PAUD have itself differencies. Implementation of religious character and intelligence potential development in their curriculum is adjusted with each institution due to absence of standard of curriculum. Learning plan areconsist of arranging annual activity plan, semester activity plan, weekly activity plan, and daily activity plan. According to the percentage of survey result, the impact of religious character development in both of PAUD is realy high. Significant average of every akhlak and its
\end{abstract}


indicators is more than $50 \%$. It proved that habituation and exemplary learning for early childhood are more effective. Result of intelligence potential development are vary due to the difference of aptitude and creativity of every child. From this research, researcher suggest the using of CTL (Contextual Teaching and Learning). It is suggested to make the teachers become more creative in developing the process of learning. As for developing intelligence potentials use the thematic development model systematically and holistically.

Keywords: early childhood, religious character, intelligence potentials

\section{Pendahuluan}

Kekuatan dan kemajuan suatu bangsa biasanya diukur dari kekuatan ekonomi, militer, teknologi dan kebudayaan bangsa tersebut. Namun yang terpenting dari semua itu adalah sumber daya manusianya. Karena manusia adalah sendi yang menjadi pusat segala elemen kekuatan yang lainnya. Maka bertitik tolak dari semua itu, segala bangsa menaruh perhatian terhadap pembentukan individu, pengembangan sumber daya manusia dan pembinaan warga secara khusus agar mereka menjadi orang yang berkarya untuk bangsa dan negara. Oleh sebab itu, pendidikan dan pengembangan SDM (dalam hal ini anak) menjadi mutlak diperlukan. Karena pendidikan adalah wahana untuk mempersiapkan manusia di dalam memecahkan problema kehidupan di masa kini maupun di masa mendatang.

Sebagai salah satu penentu keberhasilan dan kemajuan suatu bangsa, anak juga merupakan harapan terbesar bagi orang tuanya dalam melanjutkan kehidupan di dunia ini. Oleh karena itu, menurut Yusuf Muhammad al-Hasan Islam, sangat memperhatikan pendidikan anak dan pembinaan individu untuk mencapai predikat "umat terbaik". [1] Sebagaimana yang termaktub dalam Surat Ali Imran, ayat 110:

Kamu adalah umat terbaik yang dilahirkan untuk manusia, menyuruh kepada yang makruf dan mencegah dari yang munkar.

Pendidikan Islam merupakan upaya manusia untuk melahirkan generasi yang baik, generasi yang selalu menjalankan perintah Allah dan menjauhi larangan-Nya. Dalam alQur'an, Allah menjelaskan agar tidak mewariskan generasi yang lemah, sebagaimana firman Allah Surat an-Nisa ayat 9:

Dan hendaklah takut kepada Allah orang-orang yang seandainya meninggalkan di belakang mereka anak-anak yang lemah, yang mereka khawatir terhadap (kesejahteraan) mereka. Oleh sebab itu hendaklah mereka bertaqwa kepada Allah dan hendaklah mereka mengucapkan perkataan yang benar.

Sejalan dengan ayat di atas, dalam Undang-Undang Nomor 20 tahun 2003 tentang Sistem Pendidikan Nasional Pasal 1 angka 14 menyatakan bahwa Pendidikan Anak usia Dini (PAUD) adalah suatu upaya pembinaan yang ditujukan kepada anak sejak lahir sampai dengan usia enam tahun yang dilakukan melalui pemberian rangsangan pendidikan untuk membantu pertumbuhan dan perkembangan jasmani dan rohani agar anak memiliki kesiapan dalam memasuki pendidikan lebih lanjut.[2] Kesimpulan dari Undang-undang tersebut adalah melahirkan peserta didik yang menjadi insan kamil 
bukan hanya cerdas dalam segi pengetahuan saja namun cerdas dalam spiritualnya serta memiliki kepribadian yang mulia.

Oleh sebab itu, anak sebagai aset masa depan bagi orang tua, bangsa dan agama dan harus dipersiapkan dengan matang baik dalam mengembangkan kecerdasan, potensi dan karakter mereka. Karena itu menurut Widayanti, usia dini merupakan usia yang sangat penting sehingga disebut sebagai golden age dalam menentukan keberhasilannya sepanjang hayat dan masa membuat pola-pola maupun prilaku yang akan digunakan saat dewasa. Keberhasilan pembinaan pada usia dini akan berpengaruh terhadap produktivitas kerja di masa dewasanya. [3]

Menurut Zahroh, jika status gizi anak balita tidak diperbaiki, maka sel-sel otak tidak bisa berkembang dan sulit dipulihkan. Perkembangan jaringan otak dengan stimulasi mencapai $80 \%$ pada usia 0-3 tahun. Pada usia 10 tahun perkembangan jaringan otak yang sehat disertai stimulasi akan mencapai 90 \%. Maka tanpa stimulasi perkembangan jaringan otak akan jauh di bawah persentase tersebut.[4] Senada dengan hal di atas Kak Seto menambahkan, sangat jelas betapa pesat pertumbuhan anak pada rentang masa tersebut Seto[ ${ }^{5}$. Dengan kata lain, pada usia dini peluang anak dalam menyerap berbagai pengetahuan jauh lebih besar dibandingkan ketika mereka beranjak dewasa. Itu disebabkan otak[6] anak usia dini belum terkontaminasi oleh berbagai macam pengetahuan lainnya.

Ada dua tujuan diselenggarakannya pendidikan anak usia dini. Tujuan utama membentuk anak Indonesia yang berkualitas, yaitu anak yang tumbuh dan berkembang sesuai dengan tingkat perkembangannya sehingga memiliki kesiapan yang optimal dalam memasuki pendidikan dasar serta mengarungi kehidupan pada masa dewasa. Tujuan penyerta yaitu membantu menyiapkan anak mencapai kesiapan belajar (akademik) di sekolah.[7]

Hal ini juga didukung dalam pendidikan perspektif Islam, yaitu untuk mengembangkan seluruh potensi peserta didik seoptimal mungkin, baik yang menyangkut aspek jasmani, maupun rohani, akal dan akhlak. Dengan optimalisasi seluruh potensi yang dimilikinya, pendidikan Islam berupaya mengantarkan peserta didik ke arah kedewasaan pribadi secara paripurna, yaitu yang beriman dan berilmu pengetahuan. Kesemua itu diharapkan saling mempengaruhi antara satu dengan yang lain dalam perkembangannya mencapai tujuan pendidikan yang diinginkan[8] yaitu sebagai 'abd dan khalifah fi al-ardh. Salah satu sabda Rasulullah saw mengatakan:

Tiap orang dilahirkan membawa fitrah; ayah dan ibunyalah yang menjadikannya Yahudi, Nasrani atau Majusi (HR. Bukhori Muslim)[]

Menurut hadis ini, manusia lahir membawa kemampuan-kemampuan; kemampuan itulah yang disebut pembawaan. Fitrah yang disebut dalam hadis itu adalah potensi. Potensi adalah kemampuan; jadi, fitrah yang dimaksud di sini adalah pembawaan.[10]

Dengan totalitas potensi yang dimilikinya, peserta didik mampu melakukan sejumlah aktivitas dalam upaya menjaga kelangsungan eksistensi kehidupannya di muka bumi. Aktivitas yang dilakukannya, menggambarkan wujud keunikan dan dinamikanya, 
sebagai makhluk Allah yang memiliki daya kreativitas untuk berbuat dan memakmurkan alam ini. Eksistensinya bukan sekedar ada secara pasif, akan tetapi ikut mengelola alam dan sekaligus mewarnai realitas sejarah peradabannya secara aktif dan dinamis.

Namun kenyataannya sekarang, di media massa terutama di televisi sering menampilkan acara-acara yang hanya memotret dari sebagaian potensi anak saja. Hal ini justru akan membuat anak yang kalah merasa rendah diri sedangkan yang menang akan membuat mereka menjadi egois dan bangga diri. Padahal menurut Widayanti, ada banyak area yanng harus dibangun pada diri anak, baik itu afeksi, kognisi, bahasa, sosial, dan fisik. Setiap anak berbeda pada bagian mana yang paling menonjol. Jika anak dianggap hebat atau diberi bintang hanya untuk area tertentu, sangatlah tidak mewakili. Penting bagi anak, untuk merasa mampu dalam banyak hal. Hal itu, akan menentukan kesuksesannya di masa datang. Jangan sampai banyak potensi yang terpangkas hanya karena lombalomba sederhana yang diikuti pada usia dini.[11]

Seorang pakar dari Amerika Serikat, Lilian Katz, mantan Presiden National Association for the Education of Young Children (NAEYC), mengatakan bahwa pendidikan di Barat justru sudah lama meninggalkan cara-cara kompetisi yang cenderung membuat anak egois. Menurutnya, Barat kini belajar dari Timur yang lebih mengedepankan dan menumbuhkan sifat gotong royong dan kerja sama positif. Mereka justru kaget karena di Timur -khususnya Indonesia--- yang terjadi malah sebaliknya meninggalkan gotong royong dan menggalakan beraneka lomba.[12]

Selanjutnya Pamela Phelps, Direktur Creative School Florida, sangat tidak menganjurkan lomba pada anak usia dini. Menurutnya, dunia menjadi sangat kompetitif karena lomba diajarkan sejak dini. Padahal, untuk menjaga keberlangsungan dunia diperlukan sifat kerja sama saling mendukung dan melindungi, bukan dengan saling mengalahkan. Banyak dampak buruk dari perlombaan untuk anak usia dini. Hanya sedikit anak yang mendapat predikat juara dan merasa hebat, namun mematikan sebagian besar anak lainnya. Anak bisa kehilangan rasa percaya diri, mereka tidak mampu, dan kemungkinan ia memiliki konsep diri yang negatif.[13]

Oleh karena itu, pendidikan anak usia dini merupakan salah satu bentuk penyelenggaraan pendidikan yang menitikberatkan pada peletakkan dasar ke arah pertumbuhan dan perkembangan fisik (koordinasi motorik halus dan kasar), kecerdasan (daya pikir, daya cipta, kecerdasan emosi, kecerdasan spiritual), sosio-emosional (sikap dan perilaku serta agama), bahasa dan komunikasi, sesuai dengan keunikan dan tahapantahapan perkembangan yang dilalui oleh anak usia dini.

Rosyadi menambahkan, pendidikan yang diberikan kepada anak harus seimbang antara pendidikan keahlian (education for mastery) untuk mencetak anak yang produktif, pendidikan nilai-nilai agama, moral, dan etika (education for ethical standar) untuk membentuk etika dan hubungan cinta kasih dan pembentukan hati nurani (cultivition for heart) untuk membentuk kepribadian yang matang. Namun dalam kenyataannya, banyak orang tua yang hanya mementingkan pendidikan yang hanya bersifat mastery yang mengarahkan pada kemampuan intelektual tanpa memerhatikan pendidikan untuk membentuk hati nurani atau cultivition of heart. [14] 
Undang-undang Nomor 20 Tahun 2010 tentang Sistem Pendidikan Nasional, menyatakan bahwa pendidikan karakter adalah usaha sadar dan terencana untuk membangun atau membentuk kepribadian yang baik bercirikan kejujuran, tangguh, cerdas, kepedulian, bertanggung jawab, kerja keras, pantang putus asa, tanggap, percaya diri, suka menolong, mampu bersaing, profesional, ikhlas, bergotong royong, cinta tanah air, amanah, disiplin, toleransi dan taat. [15]

Tujuan pembentukan karakter adalah: pertama, untuk membentuk pribadi yang matang sehingga anak mempunyai benteng kehidupan yang kokoh dan mampu membedakan mana yang benar dan mana yang salah. Kedua, membentuk cinta kasih sejati yang seimbang antara anak dan orangtua, anak dengan anggota keluarga lainnya. Ketiga, setelah mampu membentuk kepribadian yang matang dan membangun hubungan keluarga yang harmonis, diharapkan dapat memberikan sumbangan atau kontribusi kepada orang lain atau masyarakat. Pembentukan karakter tersebut dapat dipengaruhi oleh lingkungan keluarga, lingkungan sekolah, dan lingkungan masyarakat.[16]

Untuk merealisasikan itu semua, maka dibutuhkanlah suatu lembaga baik formal maupun non formal[17] yang melaksanakan proses pembelajaran sesuai dengan kebutuhan dan usia mereka. Bukan hanya di sekolah dan tempat-tempat belajar lainnya, masjid pun juga bisa menjadi sarana penyelenggaraan PAUD. Hal ini dijelaskan Ketua Umum DMI (Dewan Masjid Indonesia) Jusuf Kalla, bahwa pendidikan membutuhkan sarana. Maka masjid merupakan sarana paling tepat. Melalui PAUD, ia ingin mendekatkan anak usia dini pada agama.[18]

Selain itu, untuk mendukung proses kegiatan pembelajaran yang dilakukan, baik pembelajaran formal maupun pembelajaran informal, diarahkan untuk menggapai tujuan pendidikan yang sebenarnya. Menurut Muhammad Amin, pendidikan sejati tidak hanya mencakup dimensi akal, tetapi juga merambah dimensi badan, perasaan, kehendak, dan seluruh unsur kejiwaan manusia serta bakat-bakat dan kemampuannya.[19] Dengan demikian, pendidikan merupakan upaya untuk mengembangkan bakat dan kemampuan individual, sehingga potensi-potensi kejiwaan itu dapat diaktualisasikan secara sempurna.

Lebih jauh, Abuddin Nata menyimpulkan bahwa tujuan pendidikan adalah membina manusia agar menjadi khalifah Allah di muka bumi. Akan tetapi, implementasi tujuan pendidikan tersebut harus disesuaikan dengan situasi dan kondisi suatu masyarakat, terutama peserta didik. Dengan demikian, implementasi tujuan pendidikan tersebut disesuaikan dengan bakat dan keahlian yang dimiliki oleh masing-masing peserta didik. Karena anak sebagai peserta didik merupakan pilar terlaksananya proses pembelajaran.[20] Sehingga apa yang telah difirmankan Allah dalam surat al-Furqon 74 benar- benar terwujud:

Dan orang orang yang berkata: "Ya Tuhan kami, anugrahkanlah kepada kami isteriisteri kami dan keturunan kami sebagai penyenang hati (Kami), dan jadikanlah kami imam bagi orang-orang yang bertakwa. 
Untuk mendukung itu semua maka dalam proses pendidikan, hendaknya tugas seorang guru harus bisa mengacu kepada tujuan pendidikan yang sebenarnya. Sebab pada hakekatnya, tugas pendidikan yang utama adalah menurut Azra terbentuknya kepribadian utama berdasarkan nilai-nilai dan ukuran Islam, sebagai sarana untuk mencapai tujuan hidup Muslim.[21] Sebagaimana firman Allah Surat al-Dzariyaat 56:

Dan Aku tidak menciptakan jin dan manusia melainkan supaya mereka menyembah$\mathrm{Ku}$.

Di tengah ramainya gaung PAUD sebagai wujud nyata dari Undang- undang tersebut, maka semua elemen masyarakat sampai kepedesaan yang dikelola oleh kaderkader PKK dan Posyandu pun menurut Nusa sebagai pemicu maraknya penyelenggaraan PAUD. [22] Salah satu pemerintah daerah yang konsent dalam penyelenggaraan PAUD adalah Pemerintahan Kota (Pemkot) Pangkalpinang sebagai ibu kota propinsi Kepulauan Bangka Belitung. Pemkot Pangkalpinang mencanangkan "1 Kelurahan 1 PAUD” dan menjadi bagian integral dari program pembangunan di Pangkalpinang[23] dengan didukung PP. 38 Tahun 2007.[24]

Walaupun PAUD sudah menjadi program nasional, namun tidak semua PAUD yang bisa melaksanakan program tersebut sesuai dengan aturan yang telah ditentukan. Khususnya, di Bangka Belitung masih banyak penyelenggaran PAUD yang menekankan proses pembelajaran kognitifnya saja berupa "CALISTUNG" (membaca, menulis, berhitung) tanpa mengembangkan atau menumbuhkan karakter dan potensi kecerdasan kepada peserta didik mereka. Hal ini disebabkan beberapa hal yang mungkin sulit direalisasikan. Antara lain: permintaan dari orang tua yang menginginkan anak mereka setelah keluar dari PAUD bisa CALISTUNG. Penyelenggara PAUD yang merasa bangga jika anak-anak mereka bisa CALISTUNG. Kemudian Sumber Daya Manusianya (Pendidik) belum memahami cara mendidik karakter bagi anak usia dini.

Permasalahannya bukan CALISTUNG tidak boleh diajarkan di PAUD, namun bagaimana cara penyampaian CALISTUNG kepada anak usia dini sesuai dengan jalan berpikir dan menciptakan jalannya sendiri dalam memahami berbagai persoalan tanpa ada beban dan paksaan dari orang lain. Dan terpenting dalam proses pembelajaran anak usia dini, seharusnya banyak dilaksanakan dengan cara bermain dengan permainan yang edukatif melalui kegiatan belajar sambil main (learning by playing) serta belajar sambil mengerjakan sesuatu (learning by doing) sesuai dengan perkembangan usia dan dunia mereka. Lebih lanjut John Holt[25] dalam bukunya How Children Fail sebagaimana yang dikutib oleh Widayanti, bahwa anak-anak berpikir dan menciptakan jalannya sendiri dalam memahami berbagai persoalan. Cara atau jalan mereka memang tidak sama seperti yang dipakai oleh orang dewasa. [26]

Kenyataan di lapangan masih banyak PAUD yang belum melaksanakan program pembelajaran sesuai dengan amanat Undang-undang. Namun di samping itu, masih ada PAUD yang pelaksanaan progran pembelajarannya sesuai dengan standar yang telah dimandatkan dalam Undang-undang Nomor 58 Tahun 2009 tentang Standar PAUD khususnya di Pangkalpinang yaitu: PAUD Ceria sebagai PAUD percontohan [27] dan sudah terakreditasi [28] di Kecamatan Gerunggang adalah salah satu PAUD yang konsisten tidak 
mengajarkan CALISTUNG[29] dan PAUD Tamasha Valaq sebagai PAUD percontohan tingkat propinsi yanng lebih menekankan pada pengembangan karakter keagamaan dalam proses pembelajarannya.

PAUD Tamasha Valaq sebagai PAUD percontohan tingkat Propinsi[30] merupakan PAUD yang menerapkan konsep keislaman dan pengembangan karakter keagamaan dalam proses pembelajaran, sehingga kalaupun ditanya para peserta didik tentang cerita Kancil dan Buaya mungkin mereka tidak tahu, namun jika ditanya tentang kisah Nabi Nuh mereka tahu dan menceritakannya dengan baik.[31] Selain itu, ada alasan yang sangat mendasar kenapa mereka mendirikan PAUD yang menekankan pada pengembangan karakter keagamaan dalam proses pembelajaran. Faktor Pertama, keprihatinan dari para Sarjana lulusan dari Jawa[32] yang melihat kondisi di Pangkalpinang khususnya, banyak sekolah misi yang menjadi favorit karena keunggulan yang mereka miliki, sehingga tidak menutup kemungkinan banyak orangtua muslim yang menyekolahkan anaknya kesana. Faktor Kedua, pada saat itu, belum ada PAUD yang menerapkan konsep keislaman dalam setiap pembelajaran. Faktor Ketiga, kalau proses pengembangan keislaman di tanamkan sedini mungkin, akan menjadi benteng mereka di masa yang akan datang.

Alasan yang mendasar penulis meneliti kedua PAUD tersebut, selain dari keunggulan yang telah dipaparkan di atas, juga informasi dan data yang didapat dari sumber yang berwenang (Dinas Pendidikan Kota Pangkalpinang) sehingga tidak akan terjadi bias dengan PAUD yang ada di Pangkalpinang khususnya. Dalam penelitian ini secara langsung dapat dilihat dengan jelas proses pelaksanaan dan implementasi pengembangan karakter keagamaan dan potensi kecerdasan anak usia dini khususnya di PAUD CERIA dan PAUD Tamasha Valaq sebagai objek penelitian.

\section{Metodologi}

Penelitian dilakukan dengan metode kualitatif, yaitu adalah metode penelitian yang digunakan untuk meneliti pada kondisi objek yang alamiah, dimana peneliti adalah sebagai instrumen kunci, pengambilan sampel sumber data dilakukan secara purposive dan snowbaal, teknik pengumpulan dengan triangulasi (gabungan), analisis data bersifat induktif/kualitatif, dan hasil penelitian kualitatif lebih menekankan makna pada generalisasi.[33]

Sesuai dengan pendekatan kualitatif, maka hasil data penelitian akan diinformasikan secara diskriptif dan tidak menguji suatu hipotesa serta tidak mengkorelasi variabel. Penelitian diskriptif adalah penelitian yang bersifat menggambarkan, menguraikan suatu hal menurut apa adanya. Maksudnya adalah data yang dikumpulkan berupa kata-kata atau penalaran, gambar dan bukan angka-angka. Hal ini disebabkan oleh adanya penerapan kualitatif.[34]

dalam penelitian ini terdiri dari dua yaitu sumber data primer dan data primer. Data primer merupakan data yang dikumpulkan, diolah peneliti dari sumber utama, yang dapat berupa kata-kata yang dihasilkan melalui wawancara. Adapun sumber data primer dalam penelitian ini adalah Dinas Pendidikan Pangkalpinang, Ketua IGRA (Ikatan Guru 
Raudhatul Atfal) dan Ketua HIMPAUDI (Himpunan Pendidikan Anak Usia Dini) Propinsi, Pengelola dan Penyelenggara PAUD Ceria dan Tamasha Valaq, Pendidik, dan perwakilan peserta didik.

Sedangkan untuk sumber data skunder dalam penelitian ini yaitu buku-buku, jurnal, buletin, majalah, koran, internet, artikel-artikel, dokumen-dokumen dan foto-foto ketika peneliti berada di lapangan.

Dikarenakan penelitian ini bersifat diskriftif maka teknis analisis datanya dilakukan secara interaktif dan berlangsung secara terus menerus dan tuntas, sampai datanya sudah jenuh. Sehingga aktivitas penelitian ini melalui reduksi data, display dan verifikasi data.[35]

\section{HASIL DAN PEMBAHASAN}

\section{A. Diskripsi Implementasi Pengembangan Karakter Keagamaan dan Potensi Kecerdasan Anak Usia Dini}

Berdasarkan data yang diperoleh di Diknas, lembaga PAUD yang ada di Pangkalpinang berjumlah 75 PAUD.[36] Namun, dalam penelitian ini hanya melihat PAUD yang sudah memenuhi dan melaksanakan dari amanat Permendiknas No. 58 Tahun 2009 tentang Standar Pendidikan Anak Usia Dini dengan mengembangkan karakter keagamaan dan potensi kecerdasan dalam proses pembelajarannya. Sehingga dari hasil penelusuran, diperoleh 2 PAUD yang memiliki kreteria tersebut, antara lain: (1) PAUD Ceria sebagai PAUD percontohan tingkat Kecamatan di bawah naungan Pemerintah, [37] (2) PAUD Tamasha Valaq sebagai PAUD percontohan/unggulan tingkat Propinsi[38] di bawah naungan yayasan.

\section{Dasar Pemikiran Pelaksanaan Pengembangan Karakter Keagamaan dan Potensi Kecerdasan Anak Usia Dini}

\section{a. PAUD Ceria}

Pada awalnya, lembaga PAUD Ceria SKB (Sanggar Kegiatan Belajar) yang beralamat di Jl. Kampung Melayu Tua Tunu Indah Kecamatan Gerunggang Kota Pangkalpinang Kepulauan Bangka Belitung bernama Lembaga TK Ceria yang didirikan pada tanggal 2 Juli 2003. Pada April 2008 Lembaga TK Ceria berganti menjadi Lembaga PAUD Ceria SKB dengan program Kelompok Bermain dan Taman Penitipan Anak. Pada bulan Juni 2012 PAUD Ceria menjadi PAUD Terpadu Ceria yang memiliki program Kelompok Bermain, Taman Penitipan Anak dan Taman Kanak-Kanak. Sedangkan penamaan PAUD Ceria agar peserta didik dalam proses pembelajaran mereka tetap ceria, senang tanpa ada beban.[39]

Sebagai lembaga non formal Negeri satu-satunya di SKB yang telah terakreditasi dengan SK badan akreditasi nasional pendidikan nonformal (BAN PNF) nomor 010/k.1/sk/akr/2013 tentang penetapan status akreditasi program dan satuan pendidikan nonformal (PNF) tahun 2013, dalam proses pembelajarannya PAUD Ceria sudah memenuhi standar yang diamanatkan dalam Permendiknas No. 58 Tahun 2009. 
Visi dari PAUD Ceria adalah: "Terwujudnya anak usia dini yang sehat, cerdas, ceria dan berakhlak, bertanggungjawab, kreatif, percaya diri, menuju terbentuknya insan cerdas komprehensif". Sedangkan Misi PAUD Ceria yaitu:

1) Meningkatkan kompetensi, keterampilan dan keteladanan bagi tenaga pendidik dan kependidikan

2) Menerapkan metode pembelajaran yang berpusat pada anak

3) Menyiapkan anak agar dapat tumbuh menjadi anak yang multi talenta

4) Mengembangkan pembelajaran anak usia dini dengan menggali kebudayaan daerah

5) Menanamkan pendidikan karakter

6) Menyediakan layanan informasi pendidikan anak usia dini

7) Mengembangkan sarana pembelajaran

Lembaga PAUD Ceria didirikan dengan tujuan untuk:

1) Membangun landasan bagi berkembangnya potensi peserta didik menjadi generasi penerus bangsa yang berakhlak mulia dan berkualitas dalam rangka mewujudkan cita-cita bangsa sesuai dengan karakter bangsa.

2) Memberi pelayanan Pendidikan Anak Usia Dini yang berkualitas sesuai dengan tahapan perkembangan anak

3) Mengembangkan seluruh potensi kecerdasan peserta didik melalui bermain yang bermakna dan menyenangkan

4) Membantu masyarakat atau lembaga PAUD disekitarnya dalam meningkatkan kualitas baik proses pembelajaran maupun manajemen lembaga.

PAUD Ceria sebagai PAUD percontohan khususnya di Kecamatan Gerungggang Kota Pangkalpinang, prestasi ini juga yang menjadikan misi dan tupoksi mereka bahwa, semua program binaanya sebagai program percontohan[40]. Secara umum, percontohan program atau satuan dapat berupa acuan untuk standarisasi komponen program atau satuan seperti diatur pada Peraturan Pemerintah Nomor 19/2005 tentang Standar Nasional Pendidikan dan Peraturan Pemerintah Nomor 32/2013 tentang Perubahan PP 19/2005 tentang SPN. Komponen dimaksud meliputi standar: komponen lulusan, isi, PTK, proses, pengelolaan, sarana-prasarana, penilaian dan pembiayaan. [41]

PAUD Ceria sebagai Lembaga Percontohan memiliki kreteria berdasarkan Petunjuk Teknis Bantuan Sosial Kelompok Percontohan Pembelajaran PAUDNI, antara lain:

Pertama, Produk Pengembangan yang direplikasi, adalah satu paket "Model Penanaman Budi Pekerti Bagi Peserta didik Kelompok bermain".

Kedua, Gambaran Model. Budi pekerti merupakan perilaku kehidupan sehari-hari dalam bergaul, berkomunikasi maupun berinteraksi antara sesama manusia atau dengan penciptanya. Oleh karena itu pendidikan budi pekerti sangat penting diberikan pada usia dini bagi pengembanan intelegensi permanen didiri anak. Tujuan Model Penanaman Budi Pekerti Bagi Peserta Didik Kelompok Bermain adalah sebagai panduan atau acuan bagi pendidik PAUD. 
Ketiga, Prasyarat Penerapan Model terdiri dari:

1) Kelembagaan/Organisasi Pengelolaan, merupakan lembaga pemerintah atau masyarakat yang memenuhi syarat minimal sebagai berikut:

a) Memiliki izin operasional/penyelenggaraan dari dinas pendidikan setempat.

b) Memiliki struktur organisasi/kepengurusan yang jelas.

c) Memiliki tempat penyelenggaraan kegiatan pembelajaran yang aman dan nyaman.

d) Memiliki peserta didik berusia 3-6 tahun dengan jumlah minimal 20 orang.

e) Memiliki data pendidik yang berpendidikan minimal SLTA, memiliki sifat sabar, tenang, ceria, keibuan, perhatian, melindungi anak, dan sanggup untuk melakukan pembelajaran.

f) Lembaga telah berdiri minimal 2 tahun.

2) Program Pembelajaran terdiri dari:

a) Perencanaan Program Pembelajaran, yang disusun oleh pendidik dengan pengelola dan mengacu pada Standar Tingkat Pencapaian Perkembangan (STPP).

b) Proses Pembelajaran, terdiri dari: Persiapan Pembelajaran, Pelaksanaan Pembelajaran, dan Penilaian Kegiatan Pembelajaran.

3) Pendanaan. Alokasi penggunaan bantuan sosial program kelompok percontohan pembelajaran PAUDNI untuk jenis bantuan PAUD pada tahun 2013 sebesar Rp. 1.400.000 per peserta didik. Rincian penggunaan dana mengacu pada satuan kelompok sebanyak 20 orang.[42]

\section{b. PAUD Tamasha Valaq}

PAUD Tamasha Valaq berdiri pada tahun 2003 dengan ijin operasional dari Dinas Pendidikan Kota Pangkalpinang Nomor: 488/Din Pen/PLS/2003 dan dilanjutkan dengan ijin perpanjangan Nomor 066/4427/Dinpendik/2007. Adapun ijin operasional untuk Taman Penitipan Anak Nomor 066/2169/Dinpendik/PNFI/2009.

Menurut Diah[43] pemberian nama PAUD Tamasha Valaq merupakan singkatan dari Taman Anak Shaleh Vaksinasi Akhlak. Filosofi dari singkatan nama tersebut, agar anakanak imun/kebal terhadap penyakit rohani karena zaman yang akan mereka hadapi nantinya akan berbeda. Lembaga penyelenggara PAUD Tamasha Valaq adalah Yayasan Shilaturrahim dengan Akta Notaris Nomor 01/Leg.Ya/ 1 / 2003 / PN. PKP. Status kepemilikan adalah milik sendiri (Yayasan Shilaturrahim) dengan luas tanah 1227 M2, luas bangunan 247 M2, yang berlokasi jl. Air Selan no.321 Pangkalpinang Propinsi Kep. Bangka Belitung.[44]

Motto Pendidikannya QS.Lukman ayat: 13

Dan (ingatlah) ketika Luqman berkata kepada anaknya, di waktu ia memberi pelajaran kepadanya: "Hai anakku, janganlah kamu mempersekutukan Allah, sesungguhnya mempersekutukan (Allah) adalah benar-benar kezaliman yang besar". 
Visi lembaganya yaitu "Mempersiapkan anak usia dini untuk menjadi generasi yang cerdas dunia dan akherat." Sedangkan Misi PAUD Tamasha Valaq yaitu:

1) Membentuk anak yang dicintai Allah, Nabi dan al-Qur'an

2) Memiliki akhlakul karimah

3) Sehat, kreatif, cerdas intelektual, emosi dan spiritual

4) Imun terhadap pengaruh nehatif dalam kehidupannya.

Sedangkan tujuan penyelenggaraan program PAUD adalah:

1) Memberikan layanan kepada anak usia 0-6 tahun yang terpaksa ditinggal orang tua karena alasan pekerjaan atau halangan lainnya.

2) Memberikan layanan yang terkait dengan pemenuhan hak-hak anak untuk tumbuh dan berkembang, mendapatkan perlindungan dan kasih sayang, serta hak-hak untuk berpartisipasi dalam lingkungan sosialnya.

Landasan hukum pelaksanaan pendirian PAUD adalah:

1) Perintah agama Islam (al-Qur'an dan al-Hadis)

2) Pembukaan UUD 1945 alenia ke-4: mencerdaskan kehidupan bangsa

3) UU No. 23 Tahun 2002 Tentang Perlindungan Anak

4) UU No. 20 Tahun 2003 Tentang Sistem Pendidikan Nasional

5) Peraturan Menteri Pendidikan Nasional no. 58 Tahun 2009 Tentang Standar Pendidikan Anak Usia Dini

\section{Pelaksanaan Standar Pendidikan Anak Usia Dini}

Dari hasil penelitian di lapangan, pelaksanaan dari ke-4 standar (tingkat pencapaian perkembangan; pendidik dan tenaga kependidikan; isi, proses dan penilaian; dan sarana dan prasarana, pengelolaan dan pembiayaan) kedua PAUD tersebut sudah mengacu kepada Permendiknas No. 58 tahun 2009, sedangkan penjabaran dari pelaksanaannya disesuaikan dengan kondisi PAUD masing-masing. Namun dalam penelitian ini hanya akan melihat pengembangaan karakter keagamaan dan potensi kecerdasaan pada tingkat perkembangan kelompok usia 4- 5 tahun.

\section{a. PAUD Ceria}

Berdasarkan dari hasil penelitian di lapangan, PAUD Ceria dalam penyelenggaraannya sudah memenuhi Standar Nasional Pendidikan yang telah diamanatkan dalam Permendiknas Nomor 58 Tahun 2009. Adapun Standar tersebut terdiri dari:

\section{1) Standar Tingkat Pencapaian Perkembangan}

Tingkat Pencapaian Perkembangan menggambarkan pertumbuhan dan perkembangan yang diharapkan dicapai anak pada rentang usia tertentu. Perkembangan anak yang dicapai merupakan integrasi pemahaman nilai-nilai agama dan moral, fisik, kognitif, bahasa, dan sosial-emosional. Pertumbuhan anak yang mencakup pemantauan 
kondisi kesehatan dan gizi mengacu pada panduan kartu menuju sehat (KMS) dan deteksi dini tumbuh kembang anak.

Perkembangan anak berlangsung secara berkesinambungan yang berarti bahwa tingkat perkembangan yang dicapai pada suatu tahap diharapkan meningkat baik secara kuantitatif maupun kualitatif pada tahap selanjutnya. Walaupun setiap anak adalah unik, karena perkembangan anak berbeda satu sama lain yang dipengaruhi oleh faktor internal dan eksternal. Namun demikian, perkembangan anak tetap mengikuti pola yang umum. Agar anak mencapai tingkat perkembangan yang optimal, dibutuhkan keterlibatan orang tua dan orang dewasa untuk memberikan rangsangan yang bersifat menyeluruh dan terpadu yang meliputi pendidikan, pengasuhan, kesehatan gizi, dan perlindungan yang diberikan secara konsisten melalui pembiasaan.

Untuk di PAUD Ceria pelaksanaan dari Standar Tingkat Pencapaian Perkembangan dilakukan dengan cara:

\section{a) Pengelompokan Usia Anak}

Berdasarkan data yang diperoleh penulis dari penyelenggara, pembagian kelompok berdasarkan kelompok usia yang termaktub dalam Permendiknas No. 58 Tahun 2009 tentang Standar Nasional Pendidikan Anak Usia Dini. Pengelompokan usia anak di PAUD Ceria yaitu:

(1) Kelompok A tahap usia 2 - 3> tahun, untuk Kelompok Bermain, terdiri dari 3 kelompok yaitu Keranji, Kelubi dan Rambai.

(2) Kelompok A tahap usia 4 - 5 tahun, untuk Taman Kanak-Kanak terdiri dari 4 kelompok yaitu jambu Bandar, Bacang, Binjai dan Manggis.

(3) Kelompo B 5- $\leq 6$ tahun, untuk Taman Kanak-Kanak terdiri dari kelompok Duren, Kelapo, dan Cempedak

\section{2) Standar Tingkat Pencapaian Perkembangan Anak}

Standar Tingkat Pencapaian Perkembangan Anak yang dilakukan di PAUD Ceria mengacu pada standar yang telah ditetapkan dalam Permendiknas Nomor. 58 tahun 2009[45], dalam penelitian ini hanya melihat Tingkat Pencapaian Perkembangan Kelompok Usia 4-- $\leq 6$ tahun

Untuk pengembangan karakter keagamaan di PAUD Ceria masuk dalam lingkup perkembangan nilai-nilai agama dan moral, sedangkan untuk pengembangan potensi kecerdasan anak masuk dalam lingkup perkembangan: Fisik (motorik kasar dan halus, dan kesehatan mental), Kognitif (pengetahuan umum dan sains, konsep bentuk, warna dan pola), konsep bilangan, lambang bilangan dan huruf), Bahasa ( Menerima bahasa, mengungkapkan bahasa dan keaksaraan), dan Sosial Emosional. Semua ruang lingkup disesuaikan dengan usia perkembangan anak.

\section{3) Standar Pendidik dan Tenaga Kependidikan}

\section{a) Standar Pendidik}

Pendidik anak usia dini adalah profesional[46] yang bertugas merencanakan, melaksanakan proses pembelajaran, dan menilai hasil pembelajaran serta melakukan 
pembimbingan, pengasuhan dan perlindungan anak didik. Pendidik PAUD bertugas di berbagai jenis layanan baik pada jalur pendidikan formal maupun nonformal seperti TK/RA, KB, TPA dan bentuk lain yang sederajat. Pendidik PAUD [ $\left.{ }^{47}\right]$ pada jalur pendidikan formal terdiri atas guru dan guru pendamping; sedangkan pendidikan PAUD pada jalur pendidikan nonformal terdiri atas guru, guru pendamping, dan pengasuh. [48]

Adapun standar yang harus dimiliki oleh Pendidik dan Tenaga Kependidikan yaitu: untuk kualifikasi dan kompetensi guru PAUD didasarkan pada Peraturan Menteri Pendidikan Nasional Republik Indonesia Nomor 16 Tahun 2007, tentang Standar Kualifikasi Akademik dan Kompetensi Guru Beserta lampirannya. Peraturan Pemerintah RI Nomor 19 Tahun 2005 Tentang Standar Nasional Pendidikan Bab VI Bagian Kesatu Pasal 29 Ayat (1) bahwa pendidik anak usia dini memiliki: (a) kualifikasi akademik pendidikan minimum diploma empat (D-IV) atau sarjana (SI); (b) latar belakang pendidikan tinggi di bidang pendidikan anak usia dini, kependidikan lain, atau psikologi; dan (c) sertifikat profesi guru untuk PAUD.[49]Sedangkan kualifikasi Akademik dan kompetensi guru pendamping harus memiliki ijazah D-II PGTK dari Perguruan Tinggi terakreditasi; atau memiliki ijazah minimal Sekolah Menengah Atas (SMA) atau sederajat dan memiliki sertifikat pelatihan/pendidikan/kursus PAUD yang terakreditasi.

Standar pendidik PAUD Ceria dapat disimpulkan sudah memenuhi kualifikasi akademik, namun untuk memenuhi pengetahuan tentang ke-PAUD-an mereka sering diikutkan dalam kegiatan magang, pelatihan dan studi banding. Untuk Standar Kompetensi pendidik berdasarkan Permendiknas Nomor. 58 tahun 2009

Berdasarkan hasil wawancara dengan ketua SKB, $\left[{ }^{50}\right]$ pengrekrutan pendidik PAUD memang sulit, hal ini disebabkan kerena kurangnya SDM dibidang ke- PAUD- an. Namun ketika sedang dilaksanakan penelitian ini, PAUD Ceria memiliki 11 orang guru, 9 dari 11 guru sedang mengambil program pendidikan S1 di UT (dengan biaya sendiri) dan 1 orang lulusan dari STAIN SAS Babel. Untuk menunjang dari kompetensi para pendidik, $\left.{ }^{51}\right]$ maka mereka pun sering diikutkan dalam kegiatan magang, studi banding, dan pembinaan khusus dari ketua yang dilaksanakan sebulan sekali.

\section{b) Standar Tenaga Kependidikan}

Profesionalitas pengelola PAUD --selaku pihak penyelenggara--mutlak diperlukan untuk memastikan efektivitas pengelolaa PAUD. Oleh sebab itu, untuk membantu anak usia dini mencapai tingkat perkembangan potensinya, layanan PAUD harus dikelola dengan baik. Setiap satuan PAUD harus memiliki penanggungjawab yang bertugas merencanakan, melaksanakan, mengelola administrasi dan biaya, serta mengawasi pelaksanaan program. Tenaga kependidikan PAUD terdiri dari atas pengawas/penilik, kepala sekolah, pengelola, tenaga administrasi, dan petugas kebersihan yang diatur sendiri oleh masing-masing lembaga.

Berdasarkan hasil wawancara dan data yang didapat dari pengelola, untuk struktur penyelenggara pada program TK, KB dan TPA seluruhnya sama. Karena ketiga program tersebut dibawah naungan program SKB. Selain memiliki kompetensi guru pendamping, pengelola PAUD harus memenuhi kompetensi seseuai dengan Permendiknas. 


\section{4) Standar Isi, Proses dan Penilaian}

Standar isi, proses dan penilaian meliputi struktur program, alokasi waktu, dan perencanaan, pelaksanaan, penilaian dilaksanakan secara terintegrasi/terpadu sesuai dengan tingkat perkembangannya, bakat/minat dan kebutuhan anak. Standar ini mempertimbangkan potensi dan kondisi setempat, sehingga dimungkinkan terjadinya perbedaan kegiatan dan pelaksanaan pendidikan, pengasuhan, dan perlindungan di lapangan. Perbedaan dapat terjadi karena adanya: (1) keragaman bentuk layanan PAUD (TK/RA, TPA, KB dan bentuk lain yang sederajat), yang menerapkan program paruh waktu dan program penuh waktu; (2) perbedaan kelompok usia yang dilayani (antara anak usia 0- $<2$ tahun dengan anak usia 2 - 4 tahun serta $4-\leq 6$ tahun); (3) perbedaan kondisi lembaga.

Perencanaan program dilakukan oleh pendidik mencakup tujuan, isi dan rencana pengelola program yang disusun dalam Rancangan Kegiatan Mingguan (RKM) dan Rencana Kegiatan Harian (RKH). Pelaksanaan program berisi proses kegiatan pendidikan, pengasuhan, perlindungan yang dirancang berdasarkan pengelompokan usia anak, dengan mempertimbangkan karakteristik perkembangan anak dan jenis layanan PAUD yang diberikan. Penilaian merupakan rangkaian kegiatan pengamatan, pencatatan, dan pengolahan data perkembangan anak dengan menggunakan metode dan instrumen yang sesuai.[52]

\section{a) Standar Isi}

\section{(1) Struktur Program}

Struktur Program kegiatan PAUD Ceria mencakup bidang pengembangan pembentukan prilaku dan bidang pengembangan kemampuan dasar melalui kegiatan bermain dan pembiasaan. Lingkup Pengembangan meliputi: (1) nilai-nilai agama dan moral, (2) fisik, (3) kognitif, (4) bahasa, dan (5) sosial emosional. Semua kegiatan pengembangan suatu aspek dilakukan secara terpadu dengan aspek yang lain menggunakan pendekatan tematik.

(2) Bentuk Kegiatan Layanan

PAUD Ceria sebagai PAUD terpadu memiliki program Taman Kanak-Kanak, Kelompok Bermain, dan Taman Penitipan Anak, yang dikelola oleh masing-masing pembimbing.

\section{(3) Alokasi waktu}

Pembagian waktu pada PAUD disesuaikan dengan kelompok usia yang telah ditentukan, antara lain; 1) kelompok usia 0 - < 2 tahun yaitu: satu kali pertemuan selama 120 menit, satu kali pertemuan per minggu, tujuh belas minggu per semester dan dua semester per tahun. 2) Kelompok uisa 2- < 4 tahun yaitu: satu kali pertemuan selama 180 menit, dua kali pertemuan per minggu, tujuah belas minggu per semester dan dua semester per tahun. 3) Kelompok usia $4-\leq 6$ tahun untukjenjang formal yaitu: satu kali pertemuan selama 150 - 180 menit, enam atau lima hari per minggu, dengan jumlah pertemuan sebanyak 900 menit (30 jam @ 30 menit), tujuh belas mingggu efektif per semester dan dua semester pertahun. Sedangkan untuk jenjang Nonformal yaitu: satu 
kali pertemuan selama 180 menit, tiga hari per minggu, tujuh belas minggu efektif per semester dan dua semester pertahun. 4) Kegiatan pengasuhan anak usia $0-\leq 6$ tahun yaitu: disesuaikan dengan sisa waktu dari penitipan dikurangi dengan kegiatan terstruktur yang sudah dilaksanakan, sesuai dengan jenis kegiatan dan kelompok usia.

(4) Rombongan belajar (Rombel)

Rombongan belajar PAUD Ceria berjumlah 10 kelompok, masing- masing kelompok berdasarkan pada usia peserta didik yang di asuh oleh 1 pendidik dan guru pendamping untuk usia 2-3 tahun dan 3-4 tahun. Taman Kanak-kanak berjumlah 7 kelompok dan 3 Kelompok Bermain, sedangkan data yang ditampilkan hanya kelompok usia 4-6 tahun

Menurut Rosmala,[53] mulai tahun ajaran 2013/2014 untuk penamaan kelompok menggunakan nama-nama buah lokal. Hal ini bertujuan untuk lebih mengenalkan kepada peserta didik nama-nama buah di Kepulauan Bangka Belitung. Sedangkan dalam proses pembelajaran di PAUD Ceria menggunakan 9 sentra, yaitu: ibadah, kreatifitas, main peran mikro, main peran makro, balok, olah tubuh, sentra musik, persiapan/keaksaraan dan bahan alam. Setiap kelompok rolling kemasing-masing sentra, tujuannya adalah untuk mengenal lebih dalam antara pendidik dan peserta didik. Sedangkan metode yang digunakan, disesuaikan dengan indikator yang dibuat oleh masing-masing guru sentra dengan menggunakan media/APE yang telah disiapkan dan disesuaikan dengan sentra.

(5) Kalender Pendidikan

Kalender pendidikan adalah pengaturan waktu untuk kegiatan pembelajaran peserta didik selama satu tahun ajaran yang mencakup permulaan tahun ajaran, minggu efektif pembelajaran, waktu pembelajaran efektif, dan hari libur. Kalender pendidikan tersebut disesuaikan dengan kondisi daerah setempat. Adapun kalender akademik terlampir

\section{b) Standar Proses}

Proses yang dilakukan dimulai dengan cara yaitu:

(1) Perencanaan

Dengan membuat, Pengembangan Rencana Pembelajaran, antara lain: 1) Perencanaan Semester, 2) Rencana Kegiatan Mingguan (RKM) dan 3) Rencana Kegiatan Harian (RKH). Sedangkan Rencana Kegiatan untuk anak usia 0 - 2 tahun bersifat individual dengan menyesuaikan jadwal harian masing-masing anak.

(2) Prinsip-prinsip

Prinsip-prinsip, yaitu: (a) memperhatikan tingkat perkembangan, kebutuhan, minat dan karakteristik anak. (b) Mengintegrasikan kesehatan gizi, pendidikan, pengasuhan dan perlindungan. (c) Pembelajaran dilaksanakan melalui bermain. (d) Kegiatan pembelajaran dilakukan secara bertahap, berkesinambungan, dan bersifat pembiasaan, dan (e) Proses pembelajaran bersifat aktif, kreatif, interaktif, efektif dan menyenangkan, dan berpusat pada anak.

(3) Pengorganisasian 
Dilakukan dengan (a) memilih metode yang tepat dan bervariasi, (b) memilih alat bermain dan sumber belajar yang ada dilingkungan, (c) memilih teknik dan alat penilaian sesuai dengan kegiatan yang dilaksanakan.

\section{(4) Pelaksanaan}

Tahapannya: (a) Penataan lingkungan bermain dengan cara menciptakan suasana bermain yang aman, nyaman, bersih dan menarik yang menggunakan alat permainan edukatif/ APE sesuai dengan standar keamanan, kesehatan, dan sesuai dengan fungsi stimulasi yang telah direncanakan serta memanfaatkan lingkungan sekitar. (b) Pengorganisasian Kegiatan, dilakukan di dalam maupun di luar ruangan/kelas dengan melihat usia anak. Untuk usia 0-2 tahun bersifat individual , usia 2- < 4 dalam kelompok besar, kelompok kecil dan individual meliputi inti dan penutup. Sedangkan usia $4-\leq 6$ dilakukan dalam individu, kelompok kecil dan kelompok besar yang meliputi pembukaan, inti dan penutup, dimana setiap kelompok usia bisa sewaktu-waktu melibatkan orang tua.

\section{c) Standar Penilaian}

Penilaian adalah proses pengumpulan dan pengolahan informasi untuk menentukan tingkat pencapaian perkembangan anak yang mencakup:Teknik Penilaian, Lingkup, Proses, Pengelolaan Hasil dan Tindak lanjut.

Menurut Rosmala, untuk melihat hasil perkembangan peserta didik, penilaian dilakukan setiap hari yang disampaikan secara lisan kepada wali siswa masing-masing. Dalam pelaksanaan tindak lanjut,para pendidik melihat dari perkembangan anak mulai masuk sampai dengan semester pertama. Jika mengalami kesulitan dalam hal perilaku dan karakter anak para pendidik bisa bekerja sama dalam menangani kasus tersebut.

\section{5) Standar Sarana dan Prasarana, Pengelolaan, dan Pembiayaan}

Standar sarana dan prasarana, pengelolaan, dan pembiayaan merupakan satu kesatuan yang tidak bisa dipisahkan dalam mendukung pelayanan PAUD. Standar sarana dan prasarana meliputi jenis, kelengkapan, dan kualitas fasilitas yang digunakan dalam menyelenggarakan proses PAUD. Standar pengelolaan merupakan kegiatan manajemen suatu lembaga PAUD yang berkaitan dengan perencanaan, pelaksanaan, dan pengawasan penyelenggaraan PAUD. Sedangkan standar pembiayaan meliputi jenis dan sumber pembiayaan yang diperlukan dalam penyelennggaraan dan pengembangan lembaga PAUD.

\section{a) Sarana dan Prasarana}

Sarana dan prasarana adalah perlengkapan untuk mendukung penyelengaraan kegiatan pendidikan, pengasuhan, dan perlindungan. Pengadaan sarana dan prasarana perlu disesuaikan dengan jumlah anak, kondisi, budaya, dan jenis layanan PAUD. Pada prinsipnya sarana dan prasarana yang dimiliki haruslah aman, nyaman, terang dan memenuhi kreteria kesehatan bagi anak, sesuai dengan tingkat perkembangan anak serta dapat memanfaatkan potensi dan sumber daya yang ada di lingkungan sekitar, termasuk barang limbang/bekas layak pakai. 
Untuk mendukung penyelenggaraan kegiatan pendidikan, pengasuhan, dan perlindungan, sarana prasarana yang dimiliki oleh PAUD Ceria yaitu: status tanah milik Pemerintah, luas tanah, status gedung dan pemanfaatan gedung, peralatan indoor dan outdoor, Alat Permainan Edukatif/ APE

Dilihat dari tabel di atas, sarana dan prasarana yang dimiliki oleh PAUD Ceria baik yang di dalam maupun di luar sudah memenuhi standar yang telah ditetapkan.

\section{b) Standar Pengelolaan}

Pengelolaan yang dimaksud untuk menjamin terpenuhinya hak dan kebutuhan anak, serta kesinambungan pelaksanaan PAUD. Prinsip pengelolaannya adalah mererapkan manajemen berbasis masyarakat, kerena jalur pendidikannya adalah nonformal. Bentuk layanannya sesuai dengan pengelompokan usia pada Taman Penitipan Anak, Kelompok Bermain dan Bentuk lain yang sederajat.

Perencanaan Pengelolaannya dengan menetapkan visi, misi dan tujuan dari lembaga PAUD Ceria yang telah dijelaskan di atas. Sedangkan untuk pengelolaan sumber belajar/ media yang meliputi pengadaan, pemanfaatan dan perawatan dengan menggunakan dana APBN melalui Diknas Pendidikan Kota Pangkalpinang.

Sedangkan untuk Pengawasan dan Evaluasi, secara internal dilakukan pembinaan khusus dari ketua yang dilakukan satu (1) bulan sekali dengan tujuan mengontrol proses pembelajaran yang sudah dilakukan, mengetahui hasil yang telah dicapai serta mengetahui kendala apa saja yang dihadapi.

\section{c) Standar Pembiayaan}

Pembiayaan meliputi jenis, sumber dan pemanfaatan, serta pengawasan dan pertanggung jawaban dalam penyelenggaraan dan pengembangan lembaga PAUD yang dikelola secara baik dan transparan.

Lebih lanjut Djuariningsih[54] menyebutkan bahwa, untuk menuju 4 standar harus didukung dana yang kuat, sehingga hasil yang dicapai bisa maksimal. Sumber dana yang didapat PAUD Ceria dari APBD dan partisipasi orang tua. Dana yang bersumber dari APBD diperuntukkan sesuai dengan anggaran yang telah ditentukan, karena PAUD Ceria sebagai bagian program SKB milik pemerintah. Sedangkan dana dari partisipasi orang tua digunakan untuk insentif lain yang diberikan kepada guru honorer. Adapun besar satuannya disesuaikan dengan lama bertugas. Untuk pengawasan dan pengontrolan dana dilakukan oleh penyelenggara dan pertanggungjawaban dilakukan oleh kepala SKB.

\section{b. PAUD Tamasha Valaq}

\section{1) Standar Tingkat Pencapaian Perkembangan}

Standar Tingkat Pencapaian Perkembangan mengacu kepada Permendiknas, yang dibagi ke dalam Pengelompokan Usia Anak dan Tingkat Pencapaian Perkembangan Anak yang semuanya disesuaikan dengan kelompok usia anak. Untuk lingkup Perekembangan yang terdiri dari: 1) Nilai-nilai agama dan moral, yang dijabarkan lagi ke dalam nilai Aqidah tauhid, Ibadah islami dan akhlaqul karimah. 2) Fisik (motorik kasar, halus dan kesehatan fisik), 3) Kognitif (pengetahuan umum dan sains, konsep bentuk, warna, dan 
pola, konsep bilangan, lambang bilangan dan huruf), 4) Bahasa (menerima bahasa, mengungkapkan bahasa, keaksaraan), 5) Sosial-emosional, yang kemudian dijabarkan ke dalam RKH, RKM, RKS, dan RKT.

\section{2) Standar Pendidik dan Tenaga Kependidikan}

Standar yang harus dimiliki oleh Pendidik di PAUD Tamasha Valaq minimal mereka pernah mengajar di TPA kemudian yang paling penting paham tentang keislaman.

Dilihat dari tabel di atas secar kualifikasi keilmuan para pendidik tidak memiliki kualifikasi ke-PAUD-an. Namun menurut Diah,[55]untuk memenuhi pemahaman dan pengalaman tentang ke-PAUD-an mereka sering diikutkan dalam pelatihan, magang dan studi banding. Sedangkan untuk tenaga administrasi dipegang oleh ibu Nopa Paliani, S.IP dan merangkap sebagai pendidik.

\section{3) Standar Isi, Proses dan Penilaian}

\section{a) Standar Isi}

(1) Program Kegiatan

Program kegiatan yang dilaksanakan di PAUD Tamasha Valaq pada tahun ajaran 2013-2014 adalah: Kelompok Belajar (KB) dan Taman Penitipan Anak (TPA) dan masingmasing program tersebut ada pembinanya

(2) Jadwal Kegiatan Harian

Jadwal Kegiatan Harian di PAUD Tamasha Valaq di buat untuk semua program yang ada, mulai dari Kelompok Bermain sampai dengan Taman Penitipan Anak.

\section{b) Standar Proses}

Standar proses yang dilakukan di PAUD Tamasha Valaq sudah mengikuti dari ketentuan yang diamanatkan dalam Permendiknas, yaitu harus membuat perencanaan pembelajaran dan melaksanakan kegiatan pembelajaran sesuai dengan perkembangan usia anak.

\section{c) Standar penilaian}

Penilaian terhadap perkembangan peserta didik berdasarkan atas pengamatan, catatan (anekdot record) dan mengumpulkan hasil kerja anak/tingkah laku sehari-hari disekolah (porto folio). Dari materi yang telah disampaikan, pendidik berkewajiban memberikan penilaian sebagai bahan evaluasi dalam hal sebagai berikut: 1) Aspek Perubahan/Pembentukan Perilaku yang Islami. 2) Aspek Perkembangan Kemapuan Dasar. Yang di dalamnya terdapat kategori penilaian yaitu: BD (Belum Dievaluasi), BM (Belum Muncul), MM (Mulai Muncul), BHS (Berkembang Sesuai Harapan), BSB (Berkembang Sangat Baik). Adapun contoh dari format penilaian dapat dilihat pada tabel di bawah ini:

\section{4) Standar Sarana dan Prasarana, Pengelolaan dan Pembiayaan}

(1) Sarana dan Prasarana 
Sarana untuk pembelajaran dapat dibedakan menjadi 2 yaitu di dalam ruangan (indoor) di luar ruangan (outdoor). Sarana Pembelajaran di dalam ruangan (indoor) antara lain: Aneka balok pembangunan, lego, hawk block dan puzzle, Alat peraga pengenalan konsep bilangan dan angka, Alat untuk bermain peran makro dan mikro, Panggung boneka dan perangkatnya, Alat permainan untuk mengenal budaya lokal/daerah lain, Perlengkapan sholat (sajadah dan mukena yang disesuikan dengan usia anak), miniatur ka'bah, Aneka pola menjahit, menabur, anyaman, dan kolase, Buku cerita keagamaan, ensiklopedia untuk anak, cerita rakyat, Seperangkat tape recorder, DVD player dan kaset, Lemari atau rak wadah APE, dan Papan tulis (white board) peserta.

Sarana pembelajaran di luar ruangan antara lain: Aneka ragam APE outdoor[56] seperti ayunan, perosotan, jungkitan, mangkok putar, titian balok, titian pelangi, jaring panjat, ring basket, kolam renang, bak pasir, sepeda (roda dua dan roda tiga) berikut areal/ treknya, rumah pohon berikut jembatan gantung dll. PAUD Tamasha Valaq juga menyediakan lingkungan yang menunjang komunikasi dan sosialisasi anak dalam suasanan kekeluargaan, menghormati, menyayangi yang syar'i serta aman sehingga anak didik dapat bereksplorasi dengan alat dan bahan mainan tanpa membahayakan keselamatan. Sedangkan untuk mendukung proses pembelajaran digunakan beberapa buku penunjang, baik bagi guru sebagai acuan dalam pembelajaran maupun sebagai referensi untuk memperkaya informasi/wawasan mengenai Pendidikan Anak Usia Dini dan juga buku-buku untuk sumber bahan ajar. Adapun buku-buku penunjang tersebut antara lain: Acuan Menu Pembelajaran Generik, PedomanTeknis Penyelenggaraan Kelompok Bermain, Biarkan Anak Bicara, The Best Of Qu'an dan Juz Amma untuk AnakAnak.[57]

\section{(2) Standar Pengelolaan}

Lembaga PAUD Tamasha Valaq dikelola berdasarkan partisipatoris, di bawah naungan Yayasan Shilaturrahim. Semua program kegiatannya berdasarkan konsep Islam yang termaktub dalam Visi, Misi dan tujuan pendiriannya.

(3) Standar Pembiayaan

Menurut Diah,[58] semua pembiayaan melalui partisipasi peserta didik. Adapun bantuan dari Diknas sifatnya insidentil. Sedangkan dana setiap kegiatan yang berlangsung di sekolah juga melalui partisipasi orang tua dan semua pengelolaan dan kepanitiaannya diserahkan kepada orang tua juga.

\section{B. Implementasi Pengembangan Karakter Keagamaan dan Potensi Kecerdasan Anak Usia Dini}

Menurut Desmita,[59] pengembangan karakter keagamaan anak usia dini, terkandung dalam lingkup perkembangan nilai-nilai agama dan moral. Sedangkan penngembangan potensi kecerdasan anak masuk dalam lingkup perkembangan motorik, kognitif, bahasa dan sosial-emosional. Secara keseluruhan kurikulum PAUD mengacu pada Permendiknas No. 58 Tahun 2009 tentang Standar Pendidikan Anak Usia Dini 
namun, dalam pelaksanaannya bervariasi dan fleksibel disesuaikan dengan lingkungan dan kondisi setempat. Adapun pelaksaan dari masing-masing PAUD tersebut akan dijelaskan lebih lanjut.

\section{PAUD Ceria}

\section{a. Kurikulum}

PAUD Ceria melaksanakan tingkat pencapaian perkembangan Anak di sesuaikan dengan Permendikas No. 58 Tahun 2009 yang memiliki lima lingkup perkembangan antara lain: nilai-nilai agama dan moral, motorik, kognitif, bahasa dan sosial-emosional. Untuk pengembangan karakter keagamaan masuk dalam lingkup perkembangan nilainilai agama dan moral. Sedangkan Pengembangan potensi kecerdasan anak masuk dalam lingkup perkembangan yaitu: Fisik (motorik kasar dan halus dan kesehatan fisik), Kognitif (pengetahuan umum dan sains, konsep bentuk (warna dan pola), konsep bilangan (lambang bilangan dan huruf), Bahasa (menerima bahasa, mengungkapkan bahasa, keaksaraan, dan Sosial-Emosional.

Dalam proses pembelajarannya dilakukan dengan menggunakan sentra[60] yang terdiri dari sentra ibadah, kreatifitas, main peran mikro, main peran makro, balok, olah tubuh, persiapan/keaksaraan, musik dan bahan alam, baik kegiatan di dalam maupun di luar ruangan. Menurut Rosmala,[61] dalam penggunaan metode masing-masing sentra, disesuaikan dengan indikator yang dibuat oleh masing-masing guru sentra.

Dari hasil penelitian serta wawancara dengan bu Mala dan bu Kris, [ ${ }^{62}$ ] PAUD Ceria sebenuhnya menjalankan kurikulum yang termaktup dalam permendiknas dan menyantumkan nilai-nilai pendidikan karakter bagi anak dari Kemendiknas serta menambahkan Character Building dan Pendidikan Antikorupsi yang tertuang dalam Menu Kegiatan Mingguan (MKM).

Penambahan pendidikan antikorupsi dalam kurikulumnya, bukanlah memberikan pemahaman kepada peserta didik tentang pengertian antikorupsi tersebut. Namun pemberian pendidikan antikorupsi kepada mereka dengan cara menanamkan nilai-nilai kejujuran, dan menghargai milik orang lain yang dilakukan dengan pembiasaan seharihari. Karena dalam konsep pemikiran anak usia dini pemahaman tersebut belum mencapai perkembangan mereka. Sedangkan untuk Character Building mereka memasukkan nilai-nilai budaya lokal melalui permainan, seni dan budaya serta penamaan sentra.

Dilihat dari contoh materi pembelajaran dalam Menu Kegiatan Mingguan, untuk pengembangan karakter keagamaan tertuang dalam lingkup perkembangan Moral. Pada contoh tersebut membahas topik bahasan hujan. Jika dikorelasikan dengan visi yang diinginkan oleh PAUD Ceria yaitu" Terwujudnya anak usia dini yang sehat, cerdas, ceria dan berakhlak, bertanggungjawab, kreatif, percaya diri, menuju terbentuknya insan cerdas komprehensif". Maka dalam visi tersebut sangat jelas disebutkan bahwa terwujudnya anak yang berakhlak. Namun dalam materi tersebut belum menyebutkan akhlak yang ingin dicapai, akan tetapi hanya menyebutkan nilai karakter yang memang telah dijelaskan dalam Kemendiknas. Hal ini bisa dikhawatirkan, para pendidik belum bisa 
membedakan mana nilai-nilai karakter dengan sifat-sifat terpuji. Nantinya juga akan memberikan dampak, bahwa nilai karakter lebih tinggi dari pada sifat-sifat terpuji yang diajarkan dalam agama Islam.

Sedangkan untuk pengembangan potensi kecerdasan anak tertuang dalam lingkup perkembangan fisik, kognitif, bahasa dan sosial. Di lembaga PAUD, memang belum ada kurikulum yang baku. Sehingga dalam realisasinya tidak terlalu ditekankan secara detail tentang aspek perkembangan yang ingin dicapai yaitu ranah kognitif (pengetahuan), afektif (sikap atau nilai) dan psikomotorik (keterampilan). Hal ini, memang kurikulum PAUD menyesuaikan dengan kondisi di lapangan dan usia perkembangan anak. Namun dalam proses pelaksanaan pengembangan potensi kecerdasan anak tetap diberikan, dengan cara belajar sambil bermain.

Dilihat dari contoh materi pembelajaran di atas belum nampak dari penjabaran pada setiap aspek perkembangan. Hal ini, disebabkan karena pembuatan materi pembelajaran terlalu singkat dan global. Berdasarkan dari analisa wawancara, untuk pembuatan kurikulum ini belum ada satu pemahaman khususnya di lembaga PAUD Pangkalpinang dan keterbatasan SDM. Ketika peneliti sedang melakukan penelitian, penjelasan dari para pendidik baru akan diadakan pelatihan untuk pembuatan kurikulum PAUD yang di koordinir oleh Dinas Pendidikan. Harapan mereka nantinya ada pembinaan yang intensif, sehingga lembaga PAUD memiliki format yang baku dalam pembuatan kurikulum khususnya berbasiskan karakter.

\section{b. Perencanaan Pembelajaran}

Perencanaan pembelajaran atau lebih dikenal dengan silabus saat ini, pada hakekatnya merupakan seperangkat rencana dan pengaturan tentang kegiatan belajar, pengelolaan kelas, dan penilaian hasil belajar. Silabus yang baik seharusnya berisikan komponen pokok yang mampu menjawab permasalah, antara lain: kompetensi apa yang akan dikembangkan pada peserta didik, bagaimana cara mengembangkannya, dan bagaimana cara mengetahui bahwa kompetensi tersebut sudah dicapai oleh peserta didik.

Untuk perencanaan pembelajaran, dimulai dengan penentuan tema yang akan disampaikan selama proses pembelajaran. Proses perencanaan pemeblajaran dengan membuat Pengembangan Rencana Pembelajaran, antara lain: 1) Perencanaan Semester, 2) Rencana Kegiatan Mingguan (RKM) dan 3) Rencana Kegiatan Harian (RKH)

Untuk tema tahunan sudah mencakup dari komponen pembuatan materi pembelajaran. Sedangkan Menu Kegiatan Mingguan (MKM) yang disampaikan di PAUD Ceria dapat dilihat pada tabel di bawah ini:

PAUD Ceria dalam penyusunan perencanaan pembelajaran mengacu kepada standar kurikulum yang dianjurkan di lembaga PAUD. Yaitu dengan memperhatikan kondisi lingkungan, memasukkan unsur budaya lokal, moment yang ada pada satu tahun kalender serta melihat perkembangan usia anak. Untuk penyusunan perencanaan pembelajaran melalui tapahan-tahapan yang telah ditentukan. Sedangkan untuk proses 
penilaian, diberikan kepada masing-masing peserta didik, setelah proses pembelajaran berakhir.

Bila dilihat dari rencana pembelajaran yang tertuang dalamm MKS, MKM dan MKH di atas, sudah dijabarkan secara rinci. Namun untuk pemberian alokasi waktu belum di tulis dengan jelas. Sehingga, dari setiap tahapan proses pembelajaran yaitu: pijakan lingkungan main, pijakan sebelum main, pijakan selama main dan pijakan setelah main tidak bisa dilihat dengan jelas.

Sedangkan untuk pemberian nilai karakter yang ingin di tampilkan dalam setiap aspek perkembangan, harus dapat membedakan nilai karakter dengan karakter keagamaan sebagaimana yang telah dijelaskan pada pembahasan kurikulum di atas.

\section{PAUD Tamasha Valaq}

\section{a. Kurikulum}

Menurut Tafsir,[63] kurikulum penting sekali dalam pendidikan anak-anak, karena tujuan-tujuan hidup yang kita yakini kebenarannya dapat dicapai melalui perencanaan kurikulum, yang di dalamnya terkandung tujuan, isi, metode atau proses belajarmengajar dan evaluasi.

Kurikulum PAUD Tamasha Valaq merupakan pedoman dalam melaksanakan program kegiatan dibuat dengan mengacu kepada prinsip-prinsip:

1) Menanamkan nilai-nilai moral dan agama dalam setiap aspek pengembangan.

2) Disesuaikan dengan kebutuhan anak, pertumbuhan dan perkembangan anak, minat dan kemampuan anak.

3) Belajar melalui Bermain

4) Belajar aktif, kreatif, inovatif, bermakna dan menyenangkan.

5) Mengoptimalkan pemanfaatan lingkungan alam sekitar sebagai sumber belajar.

6) Memasukkan unsur budaya positif daerah dalam proses pembelajaran[ $\left.{ }^{64}\right]$

Kurikulum yang dilaksanakan di PAUD Tamasha Valaq merupakan kurikulum pilihan dari Yayassan Shilaturrahim dimana PAUD Tamasha Valaq bernaung, dengan beberapa penambahan dari kurikulum BKPRMI/TAAM (Taman Asuh Anak Muslim). Akan tetapi tetap mengacu pada kurikulum nasional Pendidikan Anak Usia Dini yaitu Menu Pembelajaran Generik dan Peraturan Menteri Pendidikan Nasional RI Nomor 58 tahun 2009 tentang Standar Pendidikan Anak Usia Dini. Berdasarkan hasil analisa wawancara, maka landasan penyusunan kurikulum di PAUD Tamasha Valaq.

Melihat Misi yang diinginkan di Tamasha Valaq, yaitu untuk "Membentuk anakyang dicintai Allah, Nabi-Nya, dan al-Qur'an memiliki akhlakul karimah, sehat, kreatif, cerdas intelektual, emosi dan spiritual imun terhadap pengaruh negatif dalam kehidupan". Maka dalam visi tersebut sangat jelas disebutkan bahwa membentuk anak yang memiliki akhlakul karimah, kreatif, cerdas intelektual, emosi dan spiritual. Namun dalam materi dari setiap aspek perkembangan yang telah dibuat tersebut, belum menyebutkan secara rinci dari karakter-karakter yang ingin dicapai dalam setiap indikator yang telah ditentukan. 
Dilihat dari contoh materi pembelajaran di atas belum nampak penjabaran pada setiap aspek perkembangan. Hal ini, disebabkan karena pembuatan materi pembelajaran terlalu detail mengikuti dari standar yang telah ditentukan dalam Permendiknas. Sehingga pencapain dari nilai akhlakul karimah dari masing-masing aspek perkembangan tidak bida ditampilkan dengan jelas.

Sedangkan untuk pengembangan potensi kecerdasan anak tertuang dalam lingkup perkembangan fisik, kognitif, bahasa dan sosial. Di lembaga PAUD, memang belum ada kurikulum yang baku. Sehingga dalam realisasinya tidak terlalu ditekankan secara detail tentang aspek perkembangan yang ingin dicapai yaitu ranah kognitif (pengetahuan), afektif (sikap atau nilai) dan psikomotorik (keterampilan). Hal ini, memang kurikulum PAUD menyesuaikan dengan kondisi di lapangan dan usia perkembangan anak. Namun dalam proses pelaksanaan pengembangan potensi kecerdasan anak tetap diberikan, dengan cara belajar sambil bermain.

Untuk itu, para pendidik diharapkan lebih kreatif lagi dalam mengembangkan materi yang disampaikan dalam proses pembelajaran yang termuat dalam kurikulum. Bukan hanya untuk memenuhi dari standar yang ingin dicapai, namun mengabaikan dari unsur penting dari pengembangan karakter keagamaan dan potensi kecerdasan anak. Sehingga hasil yang dicapai nantinya lebih baik, bukan hanya sekeder memberikan pengetahuan yang mendalam. Akan tetapi proses pembelajaran anak lebih ditekankan kepada pengenalan dan pebiasaan yang dapat diaplikasikan dalam kehidupan seharihari.

\section{b. Perencanaan Pembelajaran}

Perencanaan pembelajaran atau lebih dikenal dengan silabus saat ini, pada hakekatnya merupakan seperangkat rencana dan pengaturan tentang kegiatan belajar, pengelolaan kelas, dan penilaian hasil belajar. Silabus yang baik seharusnya berisikan komponen pokok yang mampu menjawab permasalah, antara lain: kompetensi apa yang akan dikembangkan pada peserta didik, bagaimana cara mengembangkannya, dan bagaimana cara mengetahui bahwa kompetensi tersebut sudah dicapai oleh peserta didik.

Dasar awal pelaksanaan Tingkat Pencapaian Perkembangan yang dilaksanakan di PAUD Tamasha Valaq, Menurut Intan,[65]mengacu pada Permendiknas No. 58 Tahun 2009 yang mencakup 5 lingkup Perkembangan yaitu: nilai-nilai agama dan moral, Motorik, Kognitif, bahasa, dan sosialemosional. Untuk lingkup perkembangan nilai-nilai agama dan moral dikembangkan lagi dengan Aqidah Tauhid dan ibadah islami mengacu pada silabus TAAM (Taman Asuh Anak Muslim) dan beberapa program pilihan Yayasan Shilaturrahmi. Namun pada prinsipnya PAUD Tamasha Valaq tetap berpedoman pada anjuran pemerintah (Kementerian Pendidikan Nasional) dalam pembelajaran bagi anak usia dini yaitu dengan pendekatan "Belajar Melalui Berrnain yang Bermakna”.

Ruang lingkup perencanaan perencanaan berisikan Rencana Kegiatan Harian (RKH), Rencana Kegiatan Mingguan (RKM), Rencana Kegiatan Semester (RKS) dan Rencana Kegiatan Tahunan (RKT). Rencana Kegiatan Semester terdiri dari penjabaran 
Permendiknas, dan penyebaran Lingkup Perkembangan dan Tingkat Pencapaian Perkembangan masuk dalam tema 1 (satu) tahun.

Prinsip-prinsip dalam pelaksanaann perencanaan pembelajaran adalah:

1. Rencana pembelajaran memuat tujuan realitas berdasarkan pada minat dan kebutuhan anak. Tujuannya dari indikator yang disesuaikan perkembangan anak

2. Direncanakan dengan baik sehingga mendukung lingkup belajar anak.

3. Membangun pengalaman (dalam tema) indikator dan kelompok.

4. Mendukung kegiatan main yang menyenangkan, menantang dan menyatu dengan kebutuhan sehari-hari.

5. Mendukung keterlibatan orang tua (Buku Penghubung)

6. Mengembangkan wawasan anak tentang diri, lingkungan sekitar dan dunia sekeliling anak.

7. Mengembangkan aspek perkembangan.[66]

\section{Analisa Implementasi Pengembangan Karakter Keagamaan dan Potensi Kecerdasan Anak}

Berdasarkan dari implementasi pengembangan karakter keagamaan dan potensi kecerdasan anak, melalui kurikulum/materi pembelajaran dan perencanaan pembelajaran yang telah dipaparkan diatas, model yang paling efektif dalam pengembangan karakter keagamaan dan potensi kecerdasan adalah pembiasaan diri dan keteladanan dengan cara belajar sambil bermain. Pengembangan karakter keagamaan dengan kedua model tersebut anak bisa langsung dapat melihat dan menirukan apa yang disampaikan kepada mereka. Karena pembelajaran yang dilakukan melalui verbal tidak akan berjalan dengan baik dan efektif. Proses ini dapat dilihat dalam kurikulum dan perencanaan pembelajaran yang masuk dalam lingkup perkembangan nilai-nilai agama dan moral untuk pengembangan karakter keagamaan. Sedangkan pengembangan potensi kecerdasan masuk dalam lingkup perkembangan fisik, kognitif, bahasa dan sosial-emosional.

Selain kelebihan-kelebihan yang telah dijelaskan diatas, pengembangan karakter keagamaan dan potensi kecerdasan anak dalam kurikulum dan rencana pembelajaran juga memiliki kelemahan-kelemahan. Pertama, Belum adanya kurikulum di lembaga PAUD yang baku, masing-masing lembaga menyusun sesuai dengan keinginan dan pemahaman mereka. Kedua, Penentuan nilai karakater dalam setiap aspek menjadi bias dengan nilai-nilai karakter keagamaan. Ketiga, Penyusunan materi pembelajaran dalam setiap aspek perkembangan terlalu monoton, dengan format yang ada di Permendiknas. Keempat, Dalam pembuatan kurikulum dan rencana pembelajaran terlalu global dan belum terlalu menyentuh kepada materi karakternya dalam setiap aspek perkembangan. Kelima, Keterbatasan Sumber Daya Manusia membuat proses pembelajaran masih berjalan sesuai dengan keinginan mereka masing-masing. Keenam, Penambahan materi antikorupsi menambahkan permasalahan dengan pendidikan anak Usia dini. Dengan kondisi bangsa Indonesia yang dihadapkan dengan permasalahan kasus korupsi, bukan 
berarti ingin memaksakan materi antikorupsi di masukkan dalam kurikulum di lembaga PAUD.

Atas dasar dari beberapa kelemahan yang telah dijelaskan diatas, maka dapat disimpulkan bahwa, pengembangan karakter keagaman dan potensi kecerdasan anak dalam kurikulum dan rencana pembelajaran belum berjalan begitu efektif. Untuk itu, kurikulum di Lembaga PAUD segera disusun agar memberian nilai karakter dan nilai karakter keagamaan keagamaann tidak tumpang tindih. Nilai karakter keagamaan tidak hanya dijabarkan dalam aspek perkembangan nilai agama dan moral. Namun aspek perkembanngan fisik, kognitif, bahasa dan sosial emosional juga dapat dijelaskan dengan baik. Sehingga akan terlihat dengan jelas hasil pembelajaran yang berkualitas.

\section{C. Dampak Implementasi Pengembangan Karakter Keagamaan dan Potensi Kecerdasan Anak Usia Dini}

\section{Pengembangan Karakter Keagamaan dalam Lingkup Perkembangan}

Berdasarkan hasil observasi dan wawancara dengan koordinator pendidik di PAUD Ceria dapat disimpulkan bahwa, pengembangan karakter keagamaan anak yang dilaksanakan secara keseluruhan melaksanakan amanat Permendiknas No. 58 tahun 2009, yaitu Standar Tingkat Pencapaian Perkembangan Anak dalam Lingkup Perkembangan nilai-nilai agama dan moral. Untuk nilai karakter semuanya dimasukkan ke dalam indikator yang tertuang dalam Menu Kegiatan Mingguan. [67]

Adapun lingkup perkembangan nilai-nilai agama dan moral anak yang akan dibahas dalam penelitian ini baik di PAUD Ceria dan Tamasha Valaq semuanya termasuk dalam kelompok usia usia 4-5 tahun. Karena untuk usia $0-<24$ bulan dalam Lingkup Perkembangan nilai-nilai agama dan moral pada tingkat pencapaiannya tidak diatur secara spesifik, sehingga pelaksanaannya diserahkan kepada lembaga masing-masing.

Nilai karakter dimasukkan dalam indikator yang tertuang dalam Menu Kegiatan Mingguan pada setiap meteri pembelajaran.

Dilihat dari tabel di atas, maka dapat disimpulkan bahwa, di PAUD Ceria dalam proses pembelajaran sudah mengembangkan karakter keagamaan yang dituangkan dalam materi pembelajaran walupun belum menyebutkan karakter keagamaan secara konkrit dan dalam. Pemberian materi karakter keagamaan secara langsung diterapkan pada sentra agama.

Sedangkan hasil observasi dan wawancara dengan koordinator Kelompok Belajar,[68] di PAUD Tamasha Valaq dapat disimpulkan bahwa pengembangan karakter keagamaan anak yang dilaksanakan sudah melaksanakan amanat

Permendikdikna No. 58 tahun 2009, yaitu Standar Tingkat Pencapaian Perkembangan Anak dalam Lingkup Perkembangan nilai-nilai agama dan moral yang kemudian dijabarkan lagi ke dalam aqidah tauhid, ibadah islami dan akhlakul karimah. Adapun penjelasan dari penjabaran lingkup perkembangan nilai-nilai agama dan moral adalah: 


\section{a. Aqidah Tauhid}

Menurut Intan, lingkup perkembangan aqidah tauhid diberikan kepada peserta didik melalui pembiasaan dan pelaksanaan langsung, ini dilaksanakan ketika paserta didik sudah memasuki kegiatan pembelajaran yang dilaksanakan disekolah secara keseluruhan dengan agenda jurnal pagi pada jam 07.30 -07.55.

Adapun tingkat pencapaian perkembangan yang diberikan pada lingkup perkembangan Aqidah Tauhid adalah mengenal rukun Islam dengan indikator mengucapkan ikrar kerelaan secara sederhana. Ikrar kerelaan ini diucapkan dengan bersama-sama dengan metode observasi.

\section{b. Ibadah Islami}

Lingkup Perkembangan ibadah islami diberikan setelah nilai aqidah an tauhid. Pelaksanaan ibadah islami diberikan pada kegiatan pembelajaran jurnal pagi jam 07.3007.55 dan kegiatan penutup pada jam 10.00-10.30 dengan cara melafadzkan syahadat secara sederhana. Dalam Rencana Kegiatan Harian (Kelompok), pada kegiatan jurnal pagi Tingkat Pencapaian Perkembangan yaitu mengenal rukun Islam dengan indikator mengucapkan lafadz syahadat secara sederhana yang diucapkan secara beramai-ramai. Sedangkan pada kegiatan penutup, Tingkat Pencapaian Perkembangan mengenal dan menghafal do'a harian dengan indikator hafal do'a untuk orang tua dan do'a kebaikan dunia dan akherat.

\section{c. Akhlaqul Karimah}

Tingkat Pencapaian Perkembangan dari Lingkup Perkembangan akhlaqul Karimah adalah mengenal dan memahami perilaku mulia, membedakan perilaku baik dan buruk, mengucapkan kalimat thoyyibah dan menghormati agama orang lain. Nilai agama inilah yang dilaksanakan di PAUD Tamasha Valaq dalam pengembangan karakter keagamaan dimana, peserta didik mengaplikasika dalam setiap prilaku mulia dari masuk, mengikuti pembelajaran, berinteraksi baik dengan teman dan guru sampai mereka pulang.

Dalam pengembangan karakter keagamaan ini peran guru sangatlah besar, karena anak akan meniru dan melaksanakan apa yang dikatakan gurunya. Oleh sebab itu, pendidik PAUD harus lebih profesional, sabar dan memiliki karakter yang baik,[69] karena tidak semua guru bisa menjadi guru PAUD.

\section{d. Pengembangan Karakter keagamaan dalam Pembiasaan Diri}

Model pengembangan karakter keagamaan anak di PAUD Ceria dilakukan dengan pembiasaan dan keteladanan, dimana dalam pembiasaan tersebut melibatkan orang tua di rumah. Sehingga perilaku anak di rumah dan sekolah bisa sinerji. Untuk mengetahui dampak dari implementasi pengembangan karakter keagamaan dan potensi kecerdasan anak di PAUD Ceria, peneliti menyebarkan angket kepada perwakilan orang tua kelompok usia 4-5 tahun. Untuk usia 4-5 tahun ada 4 kelompok yang keseluruhannya berjumlah 69 anak, jadi masing-masing kelompok diambil 8 orang. Maka yang dijadikan responden dalam penelitian ini seluruhnya 30 perwakilan dari orang tua peserta didik. 
Model pengembangan karakter keagamaan dan potensi kecerdasan anak di PAUD Tamasha Valaq adalah dilakukan dengan pembiasaan dan keteladanan, dimana dalam pelaksanaan pembiasaan tersebut melibatkan orang tua.[70] Jadi perilaku anak di rumah dan sekolah bisa sinerji. Untuk mengetahui dampak dari implementasi pengembangan karakter keagamaan dan potensi kecerdasan anak di PAUD Tamasha Valaq, peneliti menyebarkan angket kepada perwakilan orang tua kelompok usia 4-5 tahun. Untuk usia 4-5 tahun ada 3 kelompok yang keseluruhannya berjumlah 52 anak, jadi masing-masing kelompok diambil 10 orang. Maka yang dijadikan responden dalam penelitian ini seluruhnya 30 perwakilan dari orang tua peserta didik. Karakter yang dianalisa diambil dari Laporan Penilaian Perkembangan Anak Didik dari nilai akhlaqul karimah. Adapun hasil dari angket yang dianalisa tersebut, diambil dari delapan karakter peserta didik yang sering dilaksanakan dalam keseharian mereka yaitu:

\section{1) Kejujuran}

Berbicara jujur diterapkan pada peserta didik dalam perilaku keseharian di kelas. Untuk mengetahui perilakku jujur di rumah maka melibatkan kerjasama orang tua.

Berdasarkan tabel di atas, akhlak kejujuran peserta didik bila didapat dari pada indikatornya, maka dapat diprosentasikan sebagai berikut: di PAUD Ceria, berbicara jujur dengan dimotivasi yang menyatakan sering 66\%, kadang-kadang $24 \%$ dan tidak pernah 0\%. Sedangkan di Tamasha Valaq menyatakan sering 63\%, kadang-kadang 27\% dan tidak pernah 0\%. Dari hasil tersebut dapat disimpulkan bahwa dampak dari akhlak kejujuran dengan indikator berbicara jujur sudah dapat dilaksanakan dengan baik walaupun harus sering dimotivasi. Karena dengan pembiasaan anak lebih termotivasi lagi dalam menjalankannya.

\section{2) Mengucapkan dan Menjawab Salam}

Pelaksanaan dari akhlak ini dilakukan peserta didik baik di sekolah maupun ketika di rumah.

Kebiasaan mengucapkan dan menjawab salam berdasarkan jawaban responden di PAUD Ceria hasilnya adalah yang sering melakukan sebesar 57\%, kadang-kadang 33\% dan tidak pernah $0 \%$. Sedangkan di Tamasha Valaq yang sering melakukan sebesar $63 \%$, kadang-kadang $27 \%$ dan tidak pernah $0 \%$. Kebiasaan mengucapkan dan menjawab salam peserta didik lebih banyak dibandingkan dengan menjawab kadang-kadang. Berarti peserta didik memang sudah terbiasa mengucapkan dan menjawab salam ketika mau keluar dan masuk rumah.

\section{3) Berbicara Sopan}

Akhlak berbicara sopan baik dengan guru, oranng tua, saudara dan teman.

Berdasarkan hasil angket, maka akhlak sopan peserta didik dengan indikator berbicara sopan dengan orang tua dan saudaranya adalah: PAUD Ceria yang menjawab sering $72 \%$, kadang-kadang $18 \%$ sedangkan tidak pernah $0 \%$. PAUD Tamasha Valaq yang menjawab sering 81\%, kadang-kadang 9\% sedangkan tidak pernah 0\%. Dilihat dari hasil angket tersebut, akhlak peserta didik berbicara sopan kepada oranng tua dan saudara lebih tinggi. 


\section{4) Mengucapkan Basmalah dan Hamdalah}

Akhlak mengucapkan kata basmallah dan hamdalah ketika memulai dan selesai melakukan pekerjaan. Akhlak peserta didik mengucapkan basmalah sebelum melakukan kegiatan dan mengucapkan hamdalah setelah melakukan kegiatan lebih besar dibandingkan mereka yang kadang-kadang mengucapkannya dengan hasil, PAUD Ceria $54 \%$ sering mengucapkan basmalah sebelum melakukan kegiatan dan mengucapkan hamdalah setelah melakukan kegiatan, kadang-kadang masing-masing 36\% dan tidak pernak 0\%. PAUD Tamasha Valaq 60\% sering mengucapkan basmalah sebelum melakukan kegiatan dan mengucapkan hamdalah setelah melakukan kegiatan, kadangkadang masing-masing 30\% dan tidak pernak 0\%. Jadi kesimpulannya, mereka sudah terbiasa dengan mengucapkan kalimat tersebut dalam kegiatan sehari-hari baik di rumah mapun di sekolah.

\section{5) Mengucapkan kata "Tolong" dan “Terima Kasih"}

Akhlak peserta didik mengucapkan kata "tolong" dan "terima kasih" ketika meminta bantuan kepada orang lain

Akhlak peserta didik mengucapkan kata tolong dan terima kasih untuk meminta sesuatu kepada orang lain, hasilnya di PAUD Ceria yang sering melakukan sebesar 51\%, kadang-kadang 39\% dan tidak pernah 0\%. Sedangkan di Tamasha Valaq yang sering melakukan sebesar 63\%, kadang-kadang $27 \%$ dan tidak pernah $0 \%$. Jadi kesimpulannya mereka sudah terbiasa dengan mengucapkan kalimat tersebut dan diaplikasikan dalam kehidupan sehari-hari.

\section{6) Suka Menolong}

Akhlak peserta didik dengan indikator suka menolong orang tua dan saudara, PAUD Ceria yang sering membantu sebesar 54\%, kadang-kadang 36\% dan tidak pernah 0\%. Sedangkan di Tamasha Valaq hasilnya yang sering membantu sebesar 36\%, kadangkadang 51\% dan tidak pernah 3\%. Jadi kesimpulannya untuk membantu orang tua dan saudara masih kurang karena jawaban kadang-kadang lebih besar dibandingkan dengan yang menjawab sering. Namun kalau dicermati, untuk kondisi ini, mungkin disebabkan karena mereka belum mempunyai adik atau hanya hanya tunggal, kemungkinan besar orang tua pun jarang untuk melibatkannya.

\section{7) Saling Menyayangi}

Akhlak menyayangi sesama dengan indikator tidak terbiasa mengganggu teman, tanaman, dan binatang, di PAUD ceria yang menyatakan sering 6\%, kadang-kadang 36\% dan tidak pernah 48\%. Sedangkan Di Tamasha Valaq yang menyatakan sering 45\%, kadang-kadang 30\% dan tidak pernah 15\%.

Jadi dapat disimpulkan bahwa dampak dari tidak terbiasa menggangu teman, tanaman, dan binatang belum signifikan, karena hasil yang diperoleh hampir imbang. Akan tetapi, akhlak saling menyayangi sesama sudah ada dampak positifnya.

\section{8) Meminta izin}


Akhlak peserta didik meminta izin sebelum meminjam sesuatu, PAUD Ceria hasilnya yang sering melakukan sebesar 69\%, kadang-kadang 21\% dan tidak pernah 0\%. Sedangkan PAUD Tamasha Valaq yang sering melakukan sebesar 60\%, kadang-kadang $30 \%$ dan tidak pernah $0 \%$. Jadi kesimpulannya mereka sudah terbiasa dengan mengucapkan kalimat tersebut dan diaplkasikan dalam kehidupan sehari-hari.

\section{e. Pengembangan potensi kecerdasan dalam Lingkup Perkembangan}

Berdasarkan hasil observasi dan wawancara dengan koordinator pendidik di PAUD Ceria dan Tamasha Valaq[71] dapat disimpulkan bahwa, pengembangan potensi kecerdasan anak secara keseluruhan telah melaksanakan amanat Permendiknas No. 58 tahun 2009. Standar Tingkat Pencapaian Perkembangan Anak dalam Lingkup Perkembangan yaitu: 1) Fisik (motorik kasar dan halus dan kesehatan fisik), 2) Kognitif (pengetahuan umum dan sains, konsep bentuk (warna dan pola), konsep bilangan (lambang bilangan dan huruf), 3) Bahasa (menerima bahasa, mengungkapkan bahasa, keaksaraan, dan 4) Sosial-Emosional yang dibuat dalam Rencana Kegiatan Harian (Kelompok), tertuang dalam Menu Kegiatan Mingguan.

Pemberian materi di PAUD Ceria dalam lingkup perkembangan fisik, kognitif, bahasa dan sosial emosional belum menggambarkan secara keseluruhan dari pengembangan materi tersebut. Karena pengembangan materi dari masing-masing lingkup perkembangan masih dijelaskan secara global belum dijabarkan secara spesifik. Antara lain lingkup perkembangan fisik, kognitif dan bahasa. Selain itu, PAUD Ceria dalam membuat materi pembelajaran juga belum menjelaskan dari penjabaran Fisik (motorik kasar dan halus dan kesehatan fisik), Kognitif (pengetahuan umum dan sains, konsep bentuk (warna dan pola), konsep bilangan (lambang bilangan dan huruf), Bahasa (menerima bahasa, mengungkapkan bahasa, keaksaraan),dan soaial emosional secara rinci.

Sedangkan pembuatan materi pembelajaran yang dilaksanakan di PAUD Tamasha Valaq dapat disimpulkan bahwa, pengembangan potensi kecerdasan anak secara keseluruhan telah melaksanakan amanat Permendiknas No. 58 tahun 2009. Standar Tingkat Pencapaian Perkembangan Anak dalam Lingkup Perkembangan yang mencakup: Fisik (motorik kasar dan halus dan kesehatan fisik), Kognitif (pengetahuan umum dan sains, konsep bentuk (warna dan pola), konsep bilangan (lambang bilangan dan huruf), Bahasa (menerima bahasa, mengungkapkan bahasa, keaksaraan, dan Sosial-Emosional yang dibuat dalam Rencana Kegiatan Harian (Kelompok) yang tertuang dalam Menu Kegiatan Mingguan. Untuk pelaksanaan pengembangan potensi kecerdasan anak di PAUD Tamasha Valaq dalam lingkup perkembangan.

Lingkup perkembangan fisik baik motorik kasar dan halus, secara rinci sudah menjabarkan dari pengembangan potensi kecerdasaan anak. Namun dalam memberian materi tersebut, belum tergambarkan secara detail tentang keterkaitan dari indikator yang telah disebutkan berbasiskan keagamaan. 
Lingkup perkembangan kognitif belum tergambarkan secara detail tentang keterkaitan dari indikator yang telah disebutkan berbasiskan keagamaan. Sedangkan lingkup perkembangan bahasa, sesuai dengan standar tingkat pencapaiannya.

Dalam proses pembelajaran di PAUD Tamasha Valaq sudah menjabarkan dari masing-masing lingkup perkembangan dalam standar tingkat pencapaian perkembangan anak. Namun dalam lingkup perkembangan bahasa yaitu dalam item mengungkapkan bahasa hanya mengenalkan bahasa Inggris kepada peserta didik belum memberikan materi bahasa Arab. Hal ini disebabkan karena keterbatasan sumber daya manusia. Sedangkan dalam penjabaran indikator pada masing-masing lingkup perkembangan belum menjelaskan secara mendasar tentang materi keislaman.

\section{f. Pengembangan Potensi Kecerdasan dalam Pembiasaan Diri}

Model pengembangan potensi kecerdasan anak baik yang dilakukan di lembaga PAUD Ceria dan Tamasha Valaq, dilakukan melalui pembiasaan dan kreativitas anak. Dimana dalam pelaksanaan tersebut tetap melibatkan orang tua di rumah. Sehingga orang tuapun harus mengetahui bakat -bakat yang dimiliki oleh anak mereka. Untuk mengetahui dampak dari implementasi pengembangan potensi kecerdasan anak di PAUD Ceria dan Tamasha Valaq, peneliti mengikuti proses pembelajaran yang dilaksanakan serta melihat hasil observasi yang diberikan oleh pendidik setelah proses pembelajaran berakhir. Adapun dari hasil obeservasi dari kedua PAUD tersebut dapat dilihat dalam daftar lampiran.

Selain itu, untuk mengembangkan potensi kecerdasan peserta didik, masingmasing lembaga PAUD baik di Ceria maupun Tamasha Valaq menyiapkan fasilitas untuk mendukung pengembangan bakat tersebut. Sedangkan untuk pengembangan bakat seni mereka mendatangkan pelatih khususnya di PAUD Tamasha Valaq. Sedang di PAUD Ceria mereka sudah memiliki sebagian SDM yang memilki bidang keahlian seni tersebut. Sedangkan untuk seni suara mereka bekerjasama dengan pihak luar.

Untuk mengetahui dampak dari implementasi pengembangan potensi kecerdasan dalam pembiasaan diri, baik di lembga PAUD Ceria dan Tamasha Valaq, peneliti melihat dari hasil Observasi yang diambil dari perwakilan peserta didik di sentra peran untuk PAUD Tamasha Valaq dan sentra olah tubuh di PAUD Ceria.

Berdasarkan dari hasil obsevasi yang telah dilakukan, bila didasarkan pada indikatornya maka dapat diprosentasikan sebagai berikut:

Pertama, Memanfaatkan alat permainan di luar kelas di PAUD Ceria yang tercantum dalam tabel tersebut yang sudah muncul $66 \%$, belum muncul 6\% dan yang tidak muncul 0\%. Sedangkan di PAUD Tamasha Valaq yang muncul 68\%, belum muncul 3\% sedangkan yang tidak muncul 0\%. Jika dilihat dari hasil persentasi di atas, dari masing-masing PAUD sudah ada dampak positif, karena memang anak suka dengan permainan.

Kedua, Mengekspresikan diri dengan berkarya seni menggunakan berbagai media di PAUD Ceria yang muncul 22\%, belum muncul 44\% dan yang tidak muncul 6\%. Sedangkan di PAUD Tamasha Valaq yang muncul 14\%, belum muncul 52\% dan yang tidak 
muncul 4\%. Dari hasil observasi dari indikator tersebut masih kurang, karena hasilnya lebih banyak belum muncul dalam indikator tersebut.

Berdasarkan dari hasil obsevasi yang telah dilakukan, bila didasarkan pada indikatornya maka dapat diprosentasikan sebagai berikut:

Pertama, Mengenal benda sesuai dengan fungsi di PAUD Ceria yang muncul 56\%, belum muncul $12 \%$ dan tidak muncul 4\%. Sedangkan di PAUD Tamasha Valaq yang muncul 46\%, belum muncul 12\% dan tidak muncul. Berdasarkan dari indikator tersebut hasilnya masih kurang dari kedua PAUD tersebut.

Kedua, Mengekspresikan sesuatu sesuai dengan idenya sendiri di PAUD Ceria yang muncul $48 \%$, belum muncul $16 \%$ dan yang tidak muncul $8 \%$. Sedangkan di PAUD Tamasha Valaq 46\%, belum muncul 12\% dan tidak muncul 12\%. Dari hasil tersebut, peserta didik dalam mengekspresikan sesuatu sesuai dengan idenya sendiri hasilnya masih kurang.

Ketiga, Mengklasifikasikan benda berdasarkan bentuk/warna/ukuran. Di PAUD Ceria yang sudah muncul 54\%, belum muncul 14\% dan tidak muncul 4\%. Sedangkan di PAUD Tamasha Valaq yang sudah muncul 58\%, belum muncul 8\% dan tidak muncul 4\%. Jadi dari hasil observasi tersebut dapt disipulkan bahwa kedua PAUD tersebut sudah cukup dalam mengembangkan indikator di atas.

Keempat, Mengetahui konsep banyak dan sedikit. Dari hasil observasi yang ada pada tabel di atas, maka hasilnya yaitu PAUD Ceria yang sudah muncul sebanyak 58\%, belum muncul 8\% dan tidak muncul 8\%. Sedangkan PAUD Tamasha Valaq yang sudah muncul yaitu $60 \%$, belum muncul $4 \%$ dan tidak muncul $6 \%$. Jadi kesimpulannya dari indikator yang telah dijelaskan di atas hasilnya kedua PAUD tersebut sangat efektif.

Berdasarkan dari hasil obsevasi yang telah dilakukan, bila didasarkan pada indikatornya maka dapat diprosentasikan sebagai berikut:

Pertama, Mengenal perbendaharaan kata mengenai kata sifat (nakal, pelit, baik hati, berani, jelek, dsb) di PAUD Ceria yang muncul 66\%, belum muncul 6\% dan yang tidak muncul 0\%. Sedangkan di PAUD Tamasha Valaq yang muncul 62\%, belum muncul 8\% dan yangtidak muncul 0\%. Dari hasil di atas, kedua pAUD tersebut hasilnya sudah sangat baik.

Kedua, Mengungkapkan perasaan dengan kata sifat (nakal, pelit, baik hati, berani, jelek, dsb) di PAUD Ceria yang muncul 38\%, belum muncul 18\% dan yang tidak muncul 16\%. Sedangkan di PAUD Tamasha Valaq yang muncul 36\%, belum muncul 14\% dan yang tidak muncul 20\%. Dari hasil di atas kedua PAUD tersebut, masih kurang.

Ketiga, Membuat coretan yang bermakna di PAUD Ceria yaitu muncul 34\%, belum muncul 20\% dan tidak muncul 18\%. Sedangkan di PAUD Tamasha Valaq yang muncul $38 \%$, belum muncul 22\% dan yang tidak muncul 10\%. Dari hasil diatas kedua PAUD tersebut, untuk indikator yang telah dijelaskan masih kurang dalam pengembangannya.

Berdasarkan dari hasil obsevasi yang telah dilakukan, bila didasarkan pada indikatornya maka dapat diprosentasikan sebagai berikut: 
Pertama, Menunjukkan sifat mandiri dalam memilih kegiatan di PAUD Ceria yang muncul 56\%, belum muncul 6\% dan tidak muncul 10\%. Sedangkandi PAUD Tamasha Valaq yang muncul 52\%, belum muncul 12\% dan tidak muncul 6\%. Dari hasil tersebut dapat disimpulkan, kedua PAUD tersebut cukup baik.

Kedua, Menunjukkan sifat antusiasme dalam melakukan permainan kompetitif secara positif di PAUD Ceria yanng muncul 42\%, belum muncul $16 \%$ dan tidak muncul 14\%. Sedangkan di PAUD Tamasha Valaq 48\%, belum muncul $12 \%$ dan tidak muncul 10\%. Dari hasil observasi dapat disimpilkan pada msing-masing PAUD dalam pengembangan potensi tersebut anak masih kurang.

Ketiga, Mentaati aturan dalam suatu permainan di PAUD Ceria yan sudah muncul sebanyak 50\%, belum muncul 12\% dan tidak muncul 10\%. Sedangkan di PAUD Tamasha Valaq sudang muncul 44\%, belum muncul 14\% dan tidak muncul 12\%. Jadi dapat disimpukan hasilnya dari kedua PAUD tersebut masih kurang.

Keempat, Menghargai orang lain di PAUD Ceria yang sudah muncul 60\%, belum muncul 4\% dan tidak muncul 8\%. Sedangkan di PAUD Tamasha Valaq yang sudah muncul 58\%, dan belum muncul 10\% dan tidak muncul 2\%. Dari hasil tersebut, kedua PAUD tersebut sudah baik

Dari hasil observasi yang dilakukan setelah proses pembelajaran oleh masingmasing pendidik pada perwakilan peserta didik baik di PAUD Ceria maupun Tamasha Valaq, hampir memiliki prosentase yang sama. Hal ini dimungkinkan dengan kondisi mental dan kesehatan anak pada saat mengikuti proses pembelajaran. Selain itu juga, dalam pengembangan potensi kecerdasan, masing-masing anak memiliki bakat tersendiri. Ataupun anak yang tidak menonjol dibidang seni kemungkinan besar menonjol di bidang yang lainnya

\section{KESIMPULAN}

Berdasarkan hasil penelitian yang dianalisa melalui pendekatan kualitatif deskriptif maka, ada beberapa poin yang bisa ditarik kesimpulan dalam penelitian ini, yaitu:

1. Pelaksanaan dari Permendiknas Nomor 58 Tahun 2009 tentang Standar Pendidikan Anak Usia Dini tanggal 17 September 2009 yang berisikan tentang: (1) standar tingkat pencapaian perkembangan, (2) standar pendidik dan tenaga kependidikan, (3) standar isi, proses, dan penilaian, (4) standar sarana dan prasarana, masing-masing PAUD tersebut dapat disimpulkan bahwa: PAUD Ceria dan Tamasha Valaq secara keseluruhan sudah memenuhi dari standar tersebut. Walaupun permasalahannya ada di standar pendidik yang belum memenuhi kualifikasi ke- PAUD- an. Namun untuk meningkatkan kompetensinya, mereka sering diikutkan magang, pelatihan dan studi banding. Khususnya membinaan langgsung dari pengelola PAUD. Selain itu yang paling mendasar, ketika pengrekrutan pendidik di Tamansha Valaq mereka memiliki pengetahuan keislaman yang matang dan juga pernah mengajar di TPA. 
2. Berdasarkan dari hasil penelitian dapat disimpulkan bahwa, implementasi pengembangan karakter keagamaan dan potensi kecerdasan anak yang dilihat antara lain:

Pertama, Pada dasarnya kurikulum di lembaga PAUD memang belum ada yang baku, hal ini memang kebijakan dari pusat bahwa untuk pelaksanaannya diserahkan pada lembaga masing-masing yang disesuaikan dengan kondisi daerah setempat. Akan tetapi, tetap berpedoman pada Permendiknas Nomor 58 Tahun 2009 tentang Standar Pendidikan Anak Usia Dini tanggal 17 September 2009.

Kedua, dari hasil penelitian ini penulis dapat menyimpulkan di kedua PAUD tersebut bahwa, pengembangan karakter keagamaan masuk dalam lingkup perkembangan nilai-nilai agama dan moral dengan menyantumkan nilai karakter. Sedangkan di PAUD Tamasha Valaq, untuk lingkup perkembangan Nilai-Nilai Agama dan Moral mereka jabarkan lagi dengan Aqidah Tauhid, Ibadah Islami dan Akhlaqul Karimah. Namun tetap belum mencantumkan secara jelas dari nilai karakter keagamaannya hanya menjelaskan dari pelaksanaannya saja. Hal ini dikhawatirkan, mereka tidak bisa membedakan antara nilai karakter keagamaan dan nilai karakter. Sedangkan untuk pengembangan potensi kecerdasannya dikembangkan dari lingkup perkembangan motorik, kognitif, bahasa, dan sosial-emosional, yang kesemuanya harus memperhatikan usia perkembangan peserta didik. Namun, kedua PAUD tersebut masih menjelaskan dengan secara global saja.

Ketiga, perencanaan pembelajaran yang dilaksanakan di masing-masing PAUD, tetap mengacu kepada standar yang telah ditetapka oleh Permendiknas. Dengan cara membuat RKT (Rencan Kegiatan Tahunan), RKS (Rencana Kegiatan Semester), RKM (Rencana Kegiatan Mingguan) dan RKH (Rencana Kegiatan Harian). Dan yang terpenting dalam penyusunan tersebut tetap melihat kodisi lingkungan dan usia perkembangan anak dan membangun pengetahuan secara sistematis dan holistik.

3. Sedangkan dampak dari implementasi pengembangan karakter keagamaan dan potensi kecerdasan anak melalui lingkup perkembangan dan pembiasaan diri di masing-masing PAUD tersebut adalah:

Pertama, pengembangan karakter keagamaan kedua PAUD tersebut, masuk dalam lingkup perkembangan nilai agama dan moral dengan memasukkan nilai karakter dalam materi pembelajaran. Sedangkan PAUD Tamasha Valaq dijabarkan lagi dengan Aqidah Tauhid, Ibadah islami dan Akhlakul Karimah. Namun belum menjelaskan nilai karakter keagamaannya, hanya menjelaskan dalam aspek perkembangan kognitif dan psikomotoriknya saja. Sedangkan untuk potensi kecerdasan anak masuk dalam dalam lingkup perkembangan fisik, kognitif, bahasa dan sosial-emosional.

Kedua, pengembangan karakter keagamaan melalui pembiasaan diri dapat disimpulkan bahwa kedua PAUD tersebut memiliki dampak yang sangat signifikan. Hal ini dapat dilihat dari delapan aspek tentang akhlak (Kejujuran, Mengucapkan dan Menjawab Salam, Berbicara Sopan, Mengucapkan Basmallah dan Hamdalah, Mengucapkan Kata “Tolong” dan “Terima Kasih, Suka Menolong, Saling Menyayangi, 
Meminta Izin) peserta didik yang diisi oleh perwakilan orang tua mereka, hasil angket prosentasinya sudah sangat tinggi. Rata-rata signifikansi setiap akhlak dan indikatornya lebih dari 50\%. Hal ini membuktikan, baik di PAUD Ceria dan Tamasha Valaq pengembangan karakter keagamaan peserta didik yang dilaksanakan dengan pembiasaan dalam kegiatan sehari-hari dan melihat contoh dan keteladanan dari para orang tua dan pendidik sudah berjalan dengan maksimal. Sedangkan untuk Pengembangan potensi kecerdasan anak melalui aspek fisik, kognitif, bahasa dan sosial-emosional melalui hasil observasi yang dilakukan oleh pendidik setelah proses pembelajaran hasilnya bervariasi. Hal ini disebabkan karena kondisi peserta didik pada saat itu, serta bakat dan kreativitas setiap anak adalah berbeda.

\section{REFERENCE}

[1] Yusuf Muhammad al-Hasan, Al-Wajiz Fit Tarbiyah, Penterjemah Muhammad Yusuf Harun, Pendidikan Anak Dalam Islam, Jakarta, AKAFA PRESS, Cetakan ke-. 1, 1997, hlm. 7-8.

[2] Direktorat Pendidikan Anak Usia Dini Kemendiknas Jakarta, Peraturan Menteri Pendidikan Nasional tentang Standar Pendidikan Anak Usia Dini, Jakarta, 2010, hlm. 3.

[3] Ida S. Widayanti, Mendidik Karakter dengan Karakter, Jakarta: Arga Tilanta, cetakan ke-2, 2012, hlm. 113.

4 Siti Fatimatuz Zahroh, Hubungan Antara Asupan Energi dan Protein Dengan Lama Rawat Inap Pasien Anak Umur 1-5 Tahun Di RS Khusus Anak Empat Lima Yokyakarta, Karya Tulis Ilmiah DIII. Tidak Diterbitkan. Departemen Kesehatan Republik Indonesia, Politeknik Kasehatan Yokyakarta, Jurusan Gizi, 2007.

5 LPMP Air Itam Propinsi Kepulauan Bangka Belitung, Juli 2010.

6 Dewan Editor, Enslikopedi Kemukjizatan Ilmiah dalam AL-Qur'an dan Sunnah, Jilid. 2, PT. Kharisma Ilmu, 2009, hlm. 9.

7 Indra Soefandi, S. Ahmad Pramudya, Strategi Mengembangkan Potensi Kecerdasan Anak, Jakarta: Bee Media Indonesia, 2009. hlm. 123-124.

8 Arifin H.M, Kapita Selekta Pendidikan Islam dan Umum, Jakarta: Bina Aksara, 1991, hlm. 44.

9 Ummu Ihsan Choiriyah \& Abu Ihsan al-Atsary, Mencetak Generasi Rabbani! Mendidik Buah Hati Menggapai Ridha Ilahi, Bogor: CV Darul Ilmu, 2010, 16.

10 Ahmad Tafsir, Ilmu Pendidikan Islam dalam Perspektif Islam, Bandung: Rosdakarya, cetakan ke-9. 2010, hlm. 35.

11 Ida S. Damayanti, Mendidik, hlm. 63.

12 Ibid, hlm, 62.

13 Ibid, hlm. 62-63.

14 A. Rahmat Rosyadi, Pendidikan Islam dalam Pembentukan Karakter Anak Usia Dini (Konsep dan Praktikum PAUD Islam), Jakarta: Raja Grafindo Persada, cetakan ke-1, 2013, hlm. viii.

15 Maswardi Muhammad Amin, Pendidikan Karakter Anak Bangsa, Jakarta: Baduoe Media Jakarta, 2011. hlm.14.

16 A. Rahmat Rosyadi, Pendidikan, hlm. viii-ix.

17 Direktorat Pendidikan Anak Usia Dini Kemendiknas Jakarta, Peraturan hlm. 3.

18 Republika, Selasa, 20 November 2013.

19 M. Amin Abdullah, Falsafat Kalam di Era Post Modernisme, Yokyakarta: Pustaka Pelajar, 1995, hlm. 3.

20 Abuddin Nata, Filsafat Pendidikan Islam, Jakarta: Gaya Media Pratama, 2005, hlm. 25.

21 Azyumardi Azra, Esai-Essai Intelektual Muslim pendidikan Islam, Ciputat: Logos, 1999, hlm. 6-7.

22 Nusa Putra \& Ninin Dwilestari, Penelitian Kualitatif PAUD Pendidikan Anak Usia Dini, Jakarta: Raja Grafindo Persada, 2012, hlm.vii. 
23 Hasil wawancara dengan Kepala Diknas Kota Pangkalpinang, Rabu, 28 Agustus 2013 jam. 14.00

24 Hasil wawancara dengan Sekretaris Diknas Kota Dedy Ristrianto Rabu, 28 Agustus 2013 jam 15.00

25 Ida S. Widayanti, Mendidik, hlm. 10.

26 Ibid, hlm. 10.

27 Kelembagaan Kementerian Pendidikan dan Kebudayaan Direktorat Jenderal Pendidikan Anak Usia Dini, Nonformal dan Informal, Petunjuk Teknis Bantuan Sosial Kelompok Percontohan PEMBELAJARAN PAUDNI, Jakarta, 2013.

28 SK Badan Akreditasi Nasional Pendidikan Nonformal (BAN PNF) Nomor 010/K.1/Sk/Akr/2013 Tentang Penetapan Status Akreditasi Program Dan Satuan Pendidikan Nonformal (PNF)Tahun 2013.

29 PAUD CERIA pada hari Selasa, tanggal 20 Agustus 2013, jam 09.40 WIB.

30 Kepala Diknas Pendidikan Pangkalpinang saat mewawancarai beliau pada hari Rabu Tanggal 28 Agustus 2013, dan hasil wawancara dengan ketua IGRA (Ikatan Guru Raudhatul Atfal)Propinsi Bangka Belitung ibu Rika Hartati, S.Pd. via handphone hari Jum'at tanggal 13 September 2013.

31 Hasil wawancara pada hari Rabu tanggal18 September 2013, di kantor kepala PAUD jam 09. 40. WIB.

32 Hasil wawancara dengan Kepala sekolah ibu Diah Mardiyati, di kantor PAUD hari Rabu tanggal 18 September 2013, jam 11.25-12.15 WIB.

33 Sugiono, Metode Penelitian Pendidikan: Pendekatan Kuantitatif, Kualitatif, dan R\&D Bandung: Alfabeta, 2005, hlm. 15.

34 Lexy J Moleong, Metodologi Penelitian Kualitatif, Bandung: Remaja Rosdakarya, 2002, hlm. 6.

35 Sugiyono, Metode, hlm. 337.

36 Data diambil di bagian staf Kabid PNFI, pada hari Jum'at tanggal 13 September 2013, jam 09.20 .

37 Hasil wawancara dengan Kabid PNFI ibu Hj. Aminah, S.Ip, hari Rabu tanggal 14 Agustus 2013, diruangan kabid lantai 2.

38 Hasil wawancara dengan ketua HIMPAUDI Propinsi ibu Yenni Desmita, Senin, 23 September 2013, jam. 08.40. WIB, di Kantor Kepala Sekolah TK Model jln, Pahlawan 12 Perumnas.

39 Hasil wawancara dengan kepala Tenaga Kependidikan (penyelenggara) ibu Martuti di kantor SKB pada hari Senin , tanggal 19 Agustus 2013, jam. 11.45 WIB.

40 Hasil wawancara dengan kepala SKB ibu Djuariningsih, S.Pd. di kantor SKB Pangkalpinang pada hari Selasa, tanggal 20 Agustus 2013, jam 9.40 WIB.

41 Kelembagaan Kementerian Pendidikan dan Kebudayaan Direktorat Jenderal Pendidikan Anak Usia Dini, Nonformal dan Informal, Petunjuk Teknis Bantuan Sosial Kelompok Percontohan PEMBELAJARAN PAUDNI, Jakarta, 2013, hlm. 10.

42 Ibid, hlm. 11-17.

43 Hasil wawancara dengan Direktur PAUD ibu Diah Mardiyati, A.Md. hari Selasa 17 September 2013, jam 11.25-12.15. WIB.

44 Profil PAUD TAMASHA VALAQ, 2013.

45 Peraturan Menteri....., hlm. 5-14.

46 Heck, S.F. \& William, C.R, The Complex Roles of Teachers: Anecologial Perspektive. New York: Teacher College Press, 1984.

47 Ajeng Yusriana, Kiat-Kiat Menjadi Guru PAUD yang Disukai Anak-Anak, Yokyakarta: Diva Press, 2012, hlm. 20.

48 Peraturan Menteri Pendidikan Nasional Tentang standar Pendidikan Anak Usia Dini, Jakarta: Direktorat Pendidikan Anak Usia Dini, 2010, hal. 14.

49 Kumpulan Undang-Undang dan Peraturan Pemerintah RI Tentang Pendidikan, Direktorat Jendral Pendidikan Islam Departemen Agama RI Tahun 2007, hal. 155.

50 Hasil wawancara dengan kepala SKB ibu Djuariningsih, S.Pd. di kantor SKB Pangkalpinang pada hari Selasa, tanggal 20 Agustus 2013, jam 9.40 WIB. 
51 Agus Wibowo, Pendidikan Karakter Usia Dini, Membangun Karakter Usia Dini, Yokyakarta: Pustaka Pelajar, 2012, hal. 107-130.

52 Direktorat Pendidikan Anak Usia Dini, Peraturan, hlm. 20

53 Wawancara dilakukan di Kantor Kepala PAUD, pada hari Juma'at tanggal 23 Agustus 2013 10-30.

54 Hasil wawancara pada hari Selasa, tanggal 20 Agustus 2013, jam 9.40 WIB.

55

56

57 Profil PAUD TAMASHA VALAQ.

58 Hasil wawancara dengan kepala PAUD ibu Diah Mardiyati, A.Md. hari Selasa 17 September 2013, jam 11.25-12.15. WIB.

59 Wawancara dengan ketua HIMPAUDI Propinsi ibu Yenni Desmita, Senin, 23 September 2013, jam. 08.40. WIB, di Kantor Kepala Sekolah TK Model jl. Jembatan 12 Perumnas.

60 Yuliani dan Bambang, Bermain, hlm.81.

61 Wawancara hari Jum'at tanggal 23 Agustus 2013 10.30-11.45 WIB.

62 Wawancara dengan bu Djuar, Selasa, 1 Oktober 2013 di ruang ketua.

63 Ahmad Tafsir, Ilmu Pendidikan dalam Perspektif Islam, Bandung: Remaja Rosdakarya, cetakan ke-9, 2010, hlm. 54.

64 ProfilPAUD TAMASHA VALAQ 2013.

65 Wawancara dengan ibu Septari Intan, S.Sos, sebagai koordinator Kelompok Belajar, pada tanggal 20 September 2013 di ruang sentra Ibadah Tamasha Valaq, jam 11. 30-12.25 WIB.

66 Wawancara dengan ketua HIMPAUDI Propinsi ibu Yenni Desmita, Senin, 23 September 2013, jam. 08.40. WIB, di Kantor Kepala Sekolah TK Model jln, Pahlawan 12 Perumnas.

67 Disimpulkan dari hasil wawancara dengan koordinator Kelompok Belajar dan sekaligus guru sentra Balok ibu Rosmala.

68 Disimpulkan dari hasil wawancara dengan koordinator Kelompok Belajar dan sekaligus guru sentra persiapan/keaksaraan, Septari Intan, S.Sos.

69 Agus, Pendidikan Karakter, hlm. 111-113.

70 Wawancara dengan kepala PAUD ibu Diah Mardiyati, A.Md. hari Selasa 17 September 2013, jam 11.25-12.15. WIB

71 Disimpulkan dari hasil wawancara dengan koordinator Kelompok Belajar dan sekaligus guru sentra Balok ibu Rosmala PAUD Ceria. Sedangkan wawancara di Tamasha Valaq dengan ibu Intan sebagai koordinator Kelompok Belajar dan sekaligus guru sentra persiapan/keaksaraan. 